\title{
S-ALKYLATED HOMOCYSTEINE DERIVATIVES: NEW INHIBITORS OF HUMAN BETAINE-HOMOCYSTEINE S- METHYLTRANSFERASE
}

\author{
Jiří Jiráček ${ }^{\star}, 1$, Michaela Collinsová ${ }^{1}$, Ivan Rosenberg ${ }^{*}, 1$, Miloš Buděšínský ${ }^{1}$, Eva \\ Protivínská $^{1}$, Hana Netušilová ${ }^{1}$, and Timothy A. Garrow ${ }^{2}$ \\ 1 Institute of Organic Chemistry and Biochemistry, Academy of Sciences of the Czech Republic, Flemingovo \\ nám. 2, 16610 Prague 6, Czech Republic
}

2Department of Food Science and Human Nutrition, University of Illinois, Urbana, Illinois 61801, USA

\section{Abstract}

A series of $S$-alkylated derivatives of homocysteine were synthesized and characterized as inhibitors of human recombinant betaine-homocysteine $S$-methyltransferase (BHMT). Some of these compounds inhibit BHMT with $\mathrm{IC}_{50}$ values in the nanomolar range. BHMT is very sensitive to the structure of substituents on the sulfur atom of homocysteine. The $S$-Carboxybutyl and $S$ carboxypentyl derivatives make the most potent inhibitors, and an additional sulfur atom in the alkyl chain is well tolerated. The respective $(R, S)$-5-(3-amino-3-carboxy-propylsulfanyl)-pentanoic, $(R, S)$-6-(3-amino-3-carboxy-propylsulfanyl)-hexanoic and $(R, S)$-2-amino-4-(2carboxymethylsulfanyl-ethylsulfanyl)-butyric acids are very potent inhibitors and are the strongest ever reported. We determined that $(R, S)-5$-(3-amino-3-carboxy-propylsulfanyl)-pentanoic acid displays competitive inhibition with respect to betaine binding with a $K_{\mathrm{i}}^{\text {app }}$ of $12 \mathrm{nM}$. Some of these compounds are currently being tested in mice to study the influence of BHMT on the metabolism of sulfur amino acids in vivo.

\section{Keywords}

Inhibitor; BHMT; zinc; transition-state; homocysteine derivatives

\section{INTRODUCTION}

Betaine-homocysteine S-methyltransferase (BHMT, EC 2.1.1.5) is a cytosolic enzyme that catalyzes the transfer of a methyl group from betaine to L-homocysteine forming dimethylglycine and L-methionine (Met). The reaction follows an ordered bi-bi mechanism; homocysteine is the first substrate to bind, and Met is the last product off. ${ }^{1}$ BHMT contains a zinc atom ${ }^{2}$ that is tetrahedrally coordinated by three cysteines (Cys217, Cys299 and Cys300) 3,4 and one tyrosine (Tyr160). ${ }^{5} \mathrm{The} \mathrm{Zn}^{2+}$ ion is absolutely essential for catalysis because it is required for the activation of the homocysteine thiol to the thiolate anion. 6,7 The crystal structures of BHMT indicate that it is a homotetramer. ${ }^{4,5}$ The monomeric subunit has a molecular weight of $45 \mathrm{kDa}$ and oligomerization appears to be essential for activity. 8 The enzyme is abundant in human liver and kidney, but absent from other major organs. 9 
BHMT probably has a critical role in betaine, homocysteine, methionine and $S$ adenosylmethionine (AdoMet) homeostasis. Betaine is a intermediate of choline oxidation, and in addition to its role as a methyl donor it functions also as an organic osmolyte that is kept or released by the cell in response to osmotic changes in the kidney and liver. ${ }^{10-12}$ It was recently shown that the expression of BHMT in liver and kidney is dramatically downregulated in salt loaded guinea pigs, suggesting that BHMT has a significant role modulating tissue betaine concentrations. 13

An imbalance between homocysteine formation and catabolism can result in the elevation of plasma total homocysteine (tHcy), a condition known as hyperhomocysteinemia. The most common causes of hyperhomocysteinemia are suboptimal vitamin nutrition (folate, cobalamin, and/or vitamin B6) and/or genetic mutations that cause deficiencies of enzymes required for the synthesis of methylcobalaminn, or deficiencies of methylenetetrahydrofolate reductase or cystathionine- $\beta$-synthase activities. During the last couple of decades many studies have shown that hyperhomocysteinemia represents a risk factor for the development of vascular diseases and thrombosis $14-16$, and can result in pregnancy complications. ${ }^{17,18}$ Homocysteine also has been reported to be neurotoxic ${ }^{19}$ and to be associated with an increased risk for Alzheimer's disease. ${ }^{20}$ High levels of tHcy are found also in connection with chronic renal failure. ${ }^{21}$ Since an in vitro simulation of liver metabolism suggested that half of the conversion of homocysteine to methionine was BHMT-dependent ${ }^{22}$, it is certainly possible that a genetic defect that results in reduced BHMT activity could result in hyperhomocysteinemia and confer increased risk for homocysteine-related diseases.

If it is indeed true that half of the methionine produced in liver is BHMT-dependent ${ }^{22}$, and that the vast majority of AdoMet synthesis and utilization (perhaps $\geq 85 \%$ ) occur in liver 23 , then it is reasonable to suggest that a dramatic reduction of BHMT activity also could result in reduced Met and AdoMet availability in liver, and perhaps other organs as well. The consequences of reduced Met and AdoMet biosynthesis could be many, including a reduction in transmethylation reactions (e.g. reduced DNA Methylation), but also a reduction in spermidine and spermine synthesis since the amino propyl moieties of these compounds are derived from AdoMet. Polyamines have a key role in cell growth and differentiation, and it is known that cancer cells have very high demands for AdoMet for both transmethylation reactions and polyamine synthesis. 24,25 Additionally, it is known that about half of the cysteine that is used for glutathione synthesis comes from AdoMet ${ }^{26}$, and since cysteine is a limiting reagent for glutathione synthesis, a significant reduction in BHMT activity could reduce tissue glutathione levels.

As discussed above, there is a lack of information regarding the physiological role BHMT has regulating betaine, homocysteine, methionine and AdoMet metabolism. There has been no report of a human lacking BHMT activity, nor has a BHMT knockout mouse been generated to date. In addition, there has been no report describing the use of a BHMT inhibitor in vivo to investigate the biochemical and physiological consequences of such inhibition. To study BHMT function in vivo, it would be useful to have potent, selective and metabolically stable inhibitors. Not only would such inhibitors be useful to determine whether a reduction in BHMT activity affects tHcy levels supporting or refuting whether a BHMT-related link to hyperhomocysteinemia exists, but they could be clinically useful as well. For example, it possible that transiently inhibiting BHMT would reduce betaine degradation as a mechanism to restore osmotic balance during unwanted diuresis. Or, it is possible that a BHMT inhibitor could deplete the liver of methionine and AdoMet and be part of a combined strategy to treat some forms of cancer.

To date, only a few compounds have been synthesized that inhibit BHMT in vitro, and none have been tested in vivo. The first series of BHMT inhibitors were synthesized by Awad et 
$\mathrm{al}^{27}$ in 1983. These sulfur-containing compounds were designed as transition-state $\mathbf{1}$ mimicking analogues. In Awad's study 27 , the most potent bi-substrate analogue $(R, S)-5$-(3amino-3-carboxy-propylsulfanyl)-pentanoic acid 2 (or $S$-(4-carboxybutyl)-D,L-homocysteine, CBHcy) inhibited human liver BHMT with a $K_{\mathrm{i}}^{\text {app }}$ towards betaine of $6.5 \mu \mathrm{M}$. Recently, the crystal structure of human BHMT in complex with inhibitor 2 revealed $^{4}$ that the sulfur of compound 2 became the fourth ligand to the zinc atom, confirming the biochemical evidence of a homocysteine-S-Zn interaction. In 2004, using changes in intrinsic fluorescence of BHMT, we determined $K_{\mathrm{d}}$ of compound 2 towards the enzyme to be about $280 \mathrm{nM} .{ }^{28}$ This high-affinity interaction was surprising considering the relatively high $K_{\mathrm{i}}(6.5 \mu \mathrm{M})$ reported by Awad et $\mathrm{al}^{27}$, which will be discussed later in further detail. In 1992, a series of boronic acid based analogues of betaine was published ${ }^{29}$. The most potent compound, $N, N, N-$ trimethylammonium-methylboronate $\mathbf{3}$ was a competitive inhibitor at the betaine binding site of rat liver BHMT with $K_{\mathrm{i}}$ of about $45 \mu \mathrm{M}$. Recently, we reported ${ }^{30-34}$ very selective affinity purification of rat BHMT using immobilized phosphinic pseudopeptide 4 . We determined

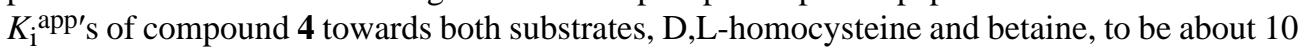
$\mu \mathrm{M}$ and we found that the type of inhibition towards both substrates is noncompetitive (Collinsova M., Jiracek J., unpublished results).
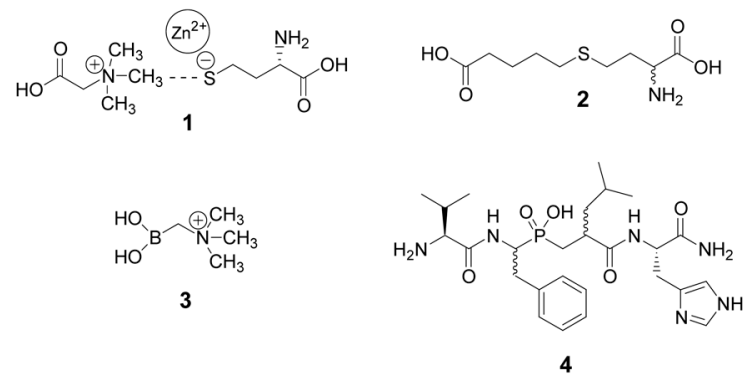

\section{RESULTS AND DISCUSSION}

We synthesized a series of $S$-alkyl derivatives of homocysteine and one $S$-alkyl derivative of cysteine. These compounds are shown in Table 1. The syntheses were performed in aqueous solutions under alkaline conditions by (i) alkylation of unprotected D,L-homocysteine (5) or L-cysteine (6) with different alkylating agents (Method A used for inhibitors 2, 8, 9, 12, 1620, 22-25), and by (ii) alkylation of respective thiols with $(R, S)$-2-amino-4-bromo-butyrate (7) (Method B used for inhibitors 13-15). Compounds 10 and 11 were prepared by the oxidation of compound 2. Compounds $\mathbf{2 6}$ and $\mathbf{2 8}$ (Table 1) are commercially available cystathionine and homocystine, respectively. Compound 27 was prepared by the oxidation of cystathionine. Table 2 shows the structures of the alkylating agents $(7, \mathbf{2 9 - 3 1}$ and 35-42) and thiols $(\mathbf{5}, \mathbf{6}$, 32-34) used to produce each product and each reaction yield.

The average yields of Methods A and B were around 30\%. The lowest yield was $2 \%$ for compound 18, probably due to the instability of its dithioformal moiety under acidic treatment, and the highest yield was $69 \%$ for compound $\mathbf{1 7}$. The average yield was relatively low, even considering the products were purified by RP-HPLC. To investigate the possibility that our low yields were due to the oxidation of homocysteine, we monitored the ratio of homocysteine/ homocystine in a reaction mixture (Method A) for $48 \mathrm{~h}$ using capillary electrophoresis (data not shown). We found that after $24 \mathrm{~h}$ the ratio was $89 / 11$, and after $48 \mathrm{~h}$ it was $20 / 80$. Since we used 3 equivalents of homocysteine to 1 equivalent of alkylating agent in our reactions, the consumption of the $S$-alkylating agent in aqueous alkaline media rather than the oxidation of homocysteine was responsible for the relatively low yields. In another experiment (Method C), we prepared compound 2 by a reaction involving the reduction of homocystine by sodium in liquid ammonia. This procedure improved our yield of compound 2 to $76 \%$, and represents 
a suitable method for the preparation of our $S$-alkylated homocysteine derivatives in higher yields. However, we used Methods A or B because they allowed us to rapidly prepare our target compounds in quantities sufficient for testing.

At first, we determined the percentage inhibition of BHMT using the test compounds at 20 $\mu \mathrm{M}$. For the most potent compounds, we then determined the percentage inhibition at $1 \mu \mathrm{M}$, and also their $\mathrm{IC}_{50}$ values. The percentages of inhibition were measured at relatively low concentrations of substrates, $0.25 \mathrm{mM}$ betaine and $100 \mu \mathrm{M}$ D,L-homocysteine $\left(K_{\mathrm{m}}\right.$ of BHMT for betaine and D,L-homocysteine is $2 \mathrm{mM}$ and $8 \mu \mathrm{M}$, respectively), in order to maximize our ability to detect inhibition. In contrast, we measured $\mathrm{IC}_{50}$ values of the most potent inhibitors at higher concentrations of substrates ( $2 \mathrm{mM}$ betaine and $1 \mathrm{mM} \mathrm{D}$,L-homocysteine) so that we could determine $\mathrm{IC}_{50}$ values in measurable concentrations and more accurately. The results of these inhibition experiments are summarized in Table 1.

Compound 2 , originally designed by Awad et al ${ }^{27}$, inhibited BHMT very strongly $\left(\mathrm{IC}_{50}\right.$ $0.087 \mu \mathrm{M}$ ). This was surprising since Awad et al reported a $K_{\mathrm{i}}$ value of only $6.5 \mu \mathrm{M}$. To investigate this discrepancy we decided to re-evaluate the $K_{\mathrm{i}}^{\text {app }}$ of this compound, which proved to be difficult because of the low $k_{\text {cat }}$ of the BHMT reaction and the high affinity of compound 2 for the enzyme. However, using a very low concentration of enzyme with high specific activity ${ }^{14} \mathrm{C}$-betaine, we determined that inhibitor 2 shows competitive inhibition relative to betaine and that is has a $K_{\mathrm{i}}^{\text {app }}$ of $12 \pm 0.9 \mathrm{nM}$ (Figure 1). Although our estimate of $K_{\mathrm{i}}^{\text {app is much }}$ lower than the value reported by Awad et al ${ }^{27}$, it is in better agreement with the $K_{\mathrm{d}}$ of the BHMT-compound 2 complex recently measured using intrinsic fluorescence ${ }^{28}$. Why is compound $\mathbf{2}$ in our hands much more potent inhibitor of BHMT than previously published by Awad et al ${ }^{27}$ The discrepancy could be that our compound was more pure. We purified compound 2 by RP-HPLC whereas they used a combination of DEAE-cellulose and Sephadex G-10 chromatography. The NMR and mass spectrometry data are not available. Therefore, it cannot be excluded that compound $\mathbf{2}$, as prepared by Awad et al, was not pure despite analyses by TLC, electrophoresis and amino acid analyzer. In addition, we used recombinant enzyme whereas Awad et al used enzyme isolated from human liver, and so it is possible that there are unknown differences in the kinetic properties of these enzymes.

The $\mathrm{IC}_{50}$ value ( $87 \mathrm{nM}$ ) obtained for compound $\mathbf{2}$ is less than half of the concentration of BHMT (200 nM) used in the assays. There is no evidence to suggest that this discrepancy can be explained by an allosteric interaction of the inhibitor with the enzyme. It is possible that the amount of active enzyme used in these reactions were overestimated since the Bradford 35 procedure cannot discern active from inactive protein. The loss of $\mathrm{Zn}^{2+}$ or enzyme denaturation could be factors that weren't corrected for. Additionally, although it is accepted that BHMT is a tetramer composed of identical subunits best described as a dimer of dimers, it is not known whether a tetramer can catalyze four reactions simultaneously. Although kinetically there is no evidence of subunit interaction, it has been shown that residues from both monomers within a dimer pair are required to form an active site $^{8}$, and that some structural elements of one monomer undergoes movement when the active site of its partner becomes occupied with ligand(s). ${ }^{28}$ Hence, it is possible that only 1 of the 2 active sites that make up a dimer can be active at any given instant.

Compounds 8 and $\mathbf{9}$ are analogues of inhibitor $\mathbf{2}$ with shorter and longer alkyl chains, respectively. Compound $\mathbf{8}$ has been already prepared by Awad et $\mathrm{al}^{27}$ and we confirmed that the shortening of carboxybutyl chain results in a drastic loss of affinity towards BHMT. On the other hand, compound $\mathbf{9}$ with carboxypentyl chain is still an excellent inhibitor of BHMT with the $\mathrm{IC}_{50}$ value only slightly weaker that that of compound $\mathbf{2}$. Compounds $\mathbf{1 0}$ and $\mathbf{1 1}$ are oxidation products of inhibitor $\mathbf{2}$. Both these compounds are much weaker inhibitors than the parent compound $\mathbf{2}$, decreasing in potency with increasing degree of oxidation at the sulfur 
atom. However, it is interesting that sulfoxide $\mathbf{1 0}$ is still much better tolerated than the shortened compound $\mathbf{8}$. We also synthesized compound $\mathbf{1 2}$, which is the "cysteine" analogue of inhibitor 2. The absolute lack of inhibition of BHMT by this compound, even at $20 \mu \mathrm{M}$ concentration, underlines the selectivity of BHMT for homocysteine.

The crystal structure of BHMT in a complex with inhibitor $\mathbf{2}$ revealed that the carboxybutyl chain of inhibitor 2 is surrounded by a series of aromatic residues ${ }^{4}$. Therefore we investigated compounds 13-15, which have a 2-, 3- or 4-carboxyphenyl group instead of the carboxybutyl moiety of inhibitor $\mathbf{2}$. Only derivative $\mathbf{1 5}$ with the 4-carboxyphenyl group replacing the carboxybutyl group in $\mathbf{2}$ is a relatively potent BHMT inhibitor with an $\mathrm{IC}_{50}$ about $7 \mu \mathrm{M}$. Inhibitor 16, with two extra methylene groups located both between the carboxyl group and phenyl ring, and the sulfur atom and phenyl ring, exhibited a marginal affinity.

Compound 17, which has the allyl group, is inactive. However, the inhibitor $\mathbf{1 8}$ of the same length as compound $\mathbf{1 7}$ but having dithioformal moiety in the chain still retains some activity. We hypothesize that the second sulfur atom of compound $\mathbf{1 8}$ could also interact with the $\mathrm{Zn}^{2+}$ of BHMT and that the analogue of 2, S-(2-carboxyethylthiomethyl)homocysteine, containing dithioformal moiety could be a very potent inhibitor of BHMT. Unfortunately, our attempts to prepare this inhibitor failed, possibly due to the low stability of $\mathrm{S}_{-} \mathrm{CH}_{2}-\mathrm{S}$ moiety under acidic conditions. This hypothesis seems to be supported by the potency we observed for compound $\mathbf{1 9}$, which is of the same length as compound $\mathbf{2}$, includes the terminal carboxylate but contains the $\mathrm{S}-\mathrm{CH}_{2}-\mathrm{CH}_{2}$-S moiety. Inhibitor 19 has about the same high affinity for BHMT as the "reference" compound 2. Sulfoxide 20 is a much weaker inhibitor of BHMT. Compound $\mathbf{2 1}$ is the mixed disulfide of D,L-homocysteine and mercaptopropionic acid. This compound is slightly more active than inhibitor $\mathbf{8}$, which has the same length.

According to Evans et $\mathrm{al}^{4}$, the carboxyl group of the carboxybutyl moiety of inhibitor $\mathbf{2}$ forms two hydrogen bonds with side chains of Tyr77 and Trp44 of BHMT. We replaced the carboxyl by the more acidic phosphonate moiety and introduced two different structural alterations into the butyl chain. Of the phosphonate analogues 22-24, only compound 22 retains significant affinity to BHMT, but it remains much weaker than compound $\mathbf{2}$. Introduction of the oxygen atom or amide bond (analogues $\mathbf{2 3}$ and $\mathbf{2 4}$ ) into the butyl chain of respective phosphonate analogues results only in further decrease of binding affinity. Compound $\mathbf{2 5}$ is the methyl ester of analogue $\mathbf{2 4}$ and the lack of affinity confirms the crucial importance of free carboxyl of the homocysteine moiety of these inhibitors.

Derivatives 26-28 are naturally occurring compounds; cystathionine, its sulfoxide and homocystine, respectively. All these compounds contain a homocysteine moiety but differ in substituents on sulfur atom. Since these compounds participate in the metabolism of sulfur amino acids and could influence activity of BHMT in vivo, we decided to test them as inhibitors of BHMT. However, none of these compounds inhibit BHMT to any significant degree. We believe that cystathionine and homocystine are not inhibitors of BHMT in vivo.

\section{CONCLUSIONS}

We synthesized a series of $S$-substituted derivatives of homocysteine and evaluated them as potential inhibitors of human recombinant BHMT. Some of these compounds are very potent inhibitors, having $\mathrm{IC}_{50}$ values in the nanomolar range. We found that compound $2,(R, S)$-5-(3amino-3-carboxy-propylsulfanyl)-pentanoic acid, is a much more potent inhibitor of BHMT than previously reported. We determined its $K_{\mathrm{i}}^{\text {app }}$ towards betaine to be about $12 \mathrm{nM}$. We found that BHMT is very sensitive to any modification in the structure of inhibitor $\mathbf{2}$ since most analogues were less active than this parent compound. Nevertheless, we found that elongating the alkyl chain by one methylene group leads to the very potent inhibitor $\mathbf{9}$, and that an 
additional sulfur atom in the otherwise alkyl chain is well tolerated (inhibitor 19). Compounds 9 and 19 are of similar potency towards BHMT as inhibitor 2 . These compounds are the most potent inhibitors of BHMT prepared to date. All these compounds were prepared as mixtures of enantiomers. Evans et $\mathrm{al}^{4}$ found that only $S$-enantiomer binds to the active site of BHMT. We assume that only $S$-enantiomers of our compounds inhibit BHMT and that respective

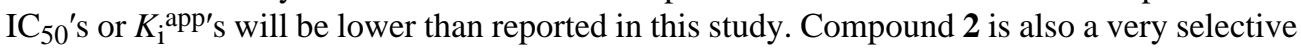
inhibitor of BHMT because it does not inhibit other enzymes involved in sulfur metabolism, such as methionine synthase, cystathionine- $\beta$-synthase and cystathionase (data not shown). Our inhibitors are currently being tested in vivo in mice to study the influence of BHMT on the metabolism of sulfur amino acids (Collinsova, Strakova, Jiracek and Garrow, manuscript submitted).

\section{EXPERIMENTAL}

\section{Chemistry. General}

Unless otherwise stated, materials were obtained from commercial suppliers (Sigma-Aldrich, Fluka, Merck) and used without purification. 4-Mercaprobenzoic acid (34) was purchased from TCI America (Portland, OR). Compound 26, R,S,R,S-2-amino-4-(2-amino-2-carboxyethylsulfanyl)-butyric acid (cystathionine) was purchased from Sigma-Aldrich. Compound 28, $R, S, R, S$-2-amino-4-(3-amino-3-carboxy-propyldisulfanyl)-butyric acid (D,Lhomocystine) was purchased from Fluka. Column chromatography was performed on silica gel 60 (70-230 mesh). Preparative RP-HPLC was performed using Vydac (218TP510, $25 \times 1$ $\mathrm{cm}$; Columbia, MD, USA) or Phenomenex (Luna C-18, $5 \mu \mathrm{m}, 25 \times 2.12 \mathrm{~cm}$, Torrance, CA,

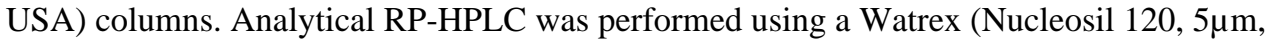
$\mathrm{C} 18,25 \times 0.46 \mathrm{~cm}$; Prague, Czech Republic) column. For gradient RP-HPLC analysis, a Waters LC 625 System (Milford, MA, USA) was used. Different gradients acetonitrile (1-80\%) in water containing $0.1 \%(\mathrm{v} / \mathrm{v})$ of TFA were used for the elution of compounds. Anion-exchange analytical HPLC was performed using a AS11-HC column $(0.2 \times 25 \mathrm{~cm}$, Dionex Corporation, Sunnyvale, CA) with a BioLC system (GP50 gradient pump, ED50 electrochemical detector) from Dionex Corporation (Sunnyvale, CA). Mass spectroscopy was performed using a ZABEQ spectrometer with BEQQ geometry (VG Analytical; Manchester, UK). NMR spectra were recorded on Bruker AVANCE-500 and Varian UNITY-500 $\left({ }^{1} \mathrm{H}\right.$ at $500 \mathrm{MHz} ;{ }^{13} \mathrm{C}$ at 125.7 $\mathrm{MHz}$ ) in $\mathrm{CDCl}_{3}$, DMSO- $d_{6}$ or $\mathrm{D}_{2} \mathrm{O}$ solutions. Chemical shifts are given in ppm (referenced to tetramethylsilane) and coupling constants in $\mathrm{Hz}$.

\section{Method A for the preparation of S-alkylated derivatives of homocysteine (used for compounds 2, 8, 9, 12, 16-20, 22-25)}

Respective halogenated agent ( 1 mmole; compounds 29-31, 35-39 and 40-42 shown in Table 2) was added to D,L-homocysteine (5) or L-cysteine (6) (3 mmoles) in 10\% sodium carbonate in $50 \%$ aqueous ethanol $(6 \mathrm{ml})$ and stirred under argon at room temperature. After $48 \mathrm{~h}$, if needed, sodium hydroxide was added to $1 \mathrm{M}$ concentration. After one $\mathrm{h}$ the reaction mixture was applied to Dowex 50W $\left(\mathrm{H}^{+}\right)$, the resin was washed with water and the compound was eluted with $2.5 \%$ ammonia. After evaporation, the product was purified by RP-HPLC.

\section{Method B for the preparation of S-alkylated derivatives of homocysteine (used for compounds 13-15)}

Respective mercapto-benzoic acid (1 mmole; compounds 32-34 shown in Table 2) was dissolved in $50 \%$ aqueous ethanol $(10 \mathrm{ml})$ containing sodium carbonate $(528 \mathrm{mg}, 5 \mathrm{mmoles})$. Then, the hydrobromide of compound 7 ( $210 \mathrm{mg}, 0.8 \mathrm{mmole}$ ) was added. The reaction was stirred under argon at room temperature overnight. The reaction mixture was applied to Dowex $50 \mathrm{~W}\left(\mathrm{H}^{+}\right)$, the resin was washed with water and the compound was eluted with $2.5 \%$ ammonia. After evaporation, the product was purified by RP-HPLC. 


\section{(R,S)-5-(3-Amino-3-carboxy-propylsulfanyl)-pentanoic acid (2)}

was first prepared according to Method A using ethyl-5-bromo-pentanoate (29; 1.2 mmoles, $251 \mathrm{mg}$ ). The yield was $88 \mathrm{mg}(31 \%) .{ }^{1} \mathrm{H}$ NMR (DMSO): $\delta 1.55(\mathrm{~m}, 4 \mathrm{H}), 1.80(\mathrm{~m}, 1 \mathrm{H}), 1.96$ $(\mathrm{m}, 1 \mathrm{H}), 2.22(\mathrm{t}, J=7.0 \mathrm{~Hz}, 2 \mathrm{H}), 2.48(\mathrm{t}, J=7.0 \mathrm{~Hz}, 1 \mathrm{H}), 2.56(\mathrm{~m}, 2 \mathrm{H}), 3.27(\mathrm{dd}, J=7.2$ and $5.6 \mathrm{~Hz}, 1 \mathrm{H}$ ); ${ }^{13} \mathrm{C}$ NMR (DMSO): $\delta 23.87,27.42,28.69,30.47,31.45,33.53,53.28,174.64$, 174.65. HR-MS (FAB) calculated for $\mathrm{C}_{9} \mathrm{H}_{18} \mathrm{NO}_{4} \mathrm{~S}\left(\mathrm{MH}^{+}\right)$236.0957, found 236.0961.

Compound $\mathbf{2}$ was also prepared according to the modified procedure (Method C) as follows. $\mathrm{D}$,L-homocystine ( $1 \mathrm{mmole}, 0.236 \mathrm{~g}$ ) was dissolved in liquid ammonia (about $30 \mathrm{ml}$ ) in a cooled flask and sodium ( 4.3 mmoles, $0.1 \mathrm{~g}$ ) was slowly added in small pieces until the reaction mixture turned blue. Ethyl-5-bromo-pentanoate acid (29;2.2 mmoles, $0.46 \mathrm{~g})$ was then added and the reaction proceeded without cooling until the ammonia was completely evaporated. The dry residue was dissolved in $30 \mathrm{ml}$ of water, and sodium hydroxide was added to $1 \mathrm{M}$ (final). After one $\mathrm{h}$, the reaction mixture was applied to Dowex 50W $\left(\mathrm{H}^{+}\right)$, and the resin was washed with water and the compound eluted with $2.5 \%$ ammonia. After evaporation, the product was purified by RP-HPLC. The yield was $0.358 \mathrm{~g}(76 \%)$. The quality of the product was verified with MS and NMR.

\section{Hydrobromide of (R,S)-2-amino-4-bromo-butyric acid (7)}

The title compound was prepared according to Farrington at $\mathrm{al}^{36}$ with several modifications. $(R, S)$-2-Amino-4-butyrolactone hydrobromide ( $1 \mathrm{~g}, 5.5 \mathrm{mmoles})$ was heated to $60-65^{\circ} \mathrm{C}$ for $48 \mathrm{~h}$ in a sealed tube with $20 \mathrm{ml}$ of hydrobromic acid (33\%) in acetic acid. The reaction mixture was evaporated to dryness and the residue was treated with diethyl ether. White crystals of the hydrobromide of $(R, S)$-2-amino-4-bromo-butyric acid (7), were washed with diethyl ether. The yield was $1.42 \mathrm{~g}(99 \%) .{ }^{1} \mathrm{H}$ NMR $\left(\mathrm{D}_{2} \mathrm{O}\right): \delta 2.43(\mathrm{~m}, J=15.2,7.3,7.2,6.1 \mathrm{~Hz}, 1 \mathrm{H}), 2.59(\mathrm{~m}$, $J=15.2,7.3,7.2,6.1 \mathrm{~Hz}, 1 \mathrm{H}), 3.62$ (ddd, $J=10.8,7.2,6.1 \mathrm{~Hz}, 1 \mathrm{H}$ ), 3.67 (ddd, $J=10.8,7.2$, $6.1 \mathrm{~Hz}, 1 \mathrm{H}), 4.26(\mathrm{t}, J=7.3,7.3 \mathrm{~Hz}, 1 \mathrm{H}) ;{ }^{13} \mathrm{C}$ NMR $\left(\mathrm{D}_{2} \mathrm{O}\right): \delta 29.92,34.68,53.44,173.30$. MS (FAB) calculated for $\mathrm{C}_{4} \mathrm{H}_{9} \mathrm{NO}_{2} \mathrm{Br}\left(\mathrm{MH}^{+}\right) 183.9796$ and 181.9817 , found 183.9796 and 181.9818.

\section{(R,S)-2-Amino-4-(3-carboxy-propylsulfanyl)-butyric acid (8)}

The title compound was prepared from ethyl-4-bromo-butyrate (30;195 mg, $1 \mathrm{mmole})$ according to Method A. The yield was $49 \mathrm{mg}(20 \%) .{ }^{1} \mathrm{H}$ NMR $\left(\mathrm{D}_{2} \mathrm{O}\right): \delta 1.90(\mathrm{p}, J=7.5 \mathrm{~Hz}$, $2 \mathrm{H}), 2.16(\mathrm{~m}, J=15.0,7.2,7.2$ and $6.8 \mathrm{~Hz}, 1 \mathrm{H}), 2.26(\mathrm{~m}, J=15.0,7.2,7.2$ and $5.9 \mathrm{~Hz}, 1 \mathrm{H})$, $2.50(\mathrm{t}, J=7.5 \mathrm{~Hz}, 2 \mathrm{H}), 2.63(\mathrm{t}, J=7.5 \mathrm{~Hz}, 2 \mathrm{H}), 2.71(\mathrm{t}, J=7.5 \mathrm{~Hz}, 2 \mathrm{H}), 4.13(\mathrm{dd}, J=6.8$ and $5.9 \mathrm{~Hz}, 1 \mathrm{H}) ;{ }^{13} \mathrm{C}$ NMR $\left(\mathrm{D}_{2} \mathrm{O}\right): \delta 26.80,28.94,32.37,32.66,35.92,55.03,175.07,180.90$; HRMS (FAB) calculated for $\mathrm{C}_{8} \mathrm{H}_{16} \mathrm{NO}_{4} \mathrm{~S}\left(\mathrm{MH}^{+}\right)$222.0800, found 222.0806 .

\section{(R,S)-6-(3-Amino-3-carboxy-propylsulfanyl)-hexanoic acid (9)}

The title compound was prepared from ethyl-6-bromo-hexanoate $(\mathbf{3 1} ; 223 \mathrm{mg}, 1 \mathrm{mmole})$ according to Method A. The yield was $68 \mathrm{mg}(27 \%) .{ }^{1} \mathrm{H}$ NMR (DMSO): $\delta 1.34(\mathrm{~m}, 2 \mathrm{H}), 1.51$ $(\mathrm{m}, 4 \mathrm{H}), 1.90(\mathrm{~m}, 1 \mathrm{H}), 2.00(\mathrm{~m}, 1 \mathrm{H}), 2.20(\mathrm{t}, J=7.4 \mathrm{~Hz}, 2 \mathrm{H}), 2.47(\mathrm{t}, J=7.3 \mathrm{~Hz}, 2 \mathrm{H}), 2.57$ (ddd, $J=13.5,9.6$ and $5.6 \mathrm{~Hz}, 1 \mathrm{H}$ ), 2.60 (ddd, $J=13.5,9.5$ and $6.5 \mathrm{~Hz}, 1 \mathrm{H}$ ), 3.63 (dd, $J=6.5$ and $5.6 \mathrm{~Hz}, 1 \mathrm{H}$ ); ${ }^{13} \mathrm{C}$ NMR (DMSO): $\delta 24.27,26.91,27.92,28.90,30.67,31.01,33.85,52.34$, $170.58,174.66$; HR-MS (FAB) calculated for $\mathrm{C}_{10} \mathrm{H}_{20} \mathrm{NO}_{4} \mathrm{~S}\left(\mathrm{MH}^{+}\right) 250.1035$, found 250.1059 .

\section{(R,S)-5-(3-Amino-3-carboxy-propylsulfinyl)-pentanoic acid (10)}

Compound 2 (10 mg, $42 \mu$ moles) was suspended in $100 \mu$ l of water containing $46 \mu$ moles of hydrochloric acid and $50 \mu$ moles of hydrogen peroxide. The suspension was stirred at room temperature overnight. The product was purified by RP-HPLC. The yield was $9 \mathrm{mg}$ ( 85 $\%) .{ }^{1} \mathrm{H}$ NMR $\left(\mathrm{D}_{2} \mathrm{O}\right): \delta 1.70-1.80(\mathrm{~m}, 4 \mathrm{H}), 2.25-2.37(\mathrm{~m}, 4 \mathrm{H}), 2.90-3.15(\mathrm{~m}, 4 \mathrm{H}) ;{ }_{13} \mathrm{C}$ NMR 
$\left(\mathrm{D}_{2} \mathrm{O}\right)$ : mixture of diastereoisomers (1:1) leads to doubling of some carbon signals (shown in brackets), $\delta 23.94$ (23.96), 26.10 (26.15), 26.79, 38.65, 48.38 (48.40), 52.44 (52.52), 55.56 (55.74), 175.40, 184.65; HR-MS (FAB) calculated for $\mathrm{C}_{9} \mathrm{H}_{18} \mathrm{NO}_{5} \mathrm{~S}\left(\mathrm{MH}^{+}\right) 252.0906$, found 252.0895 .

\section{(R,S)-5-(3-Amino-3-carboxy-propylsulfonyl)-pentanoic acid (11)}

Compound 2 (10 mg, $42 \mu$ moles) was suspended in $100 \mu$ l of water containing $450 \mu$ moles of hydrochloric acid and $200 \mu$ moles of hydrogen peroxide. The suspension was stirred at room temperature overnight. The product was purified by RP-HPLC. The yield was $7.3 \mathrm{mg}$ (65 \%). ${ }^{1} \mathrm{H}$ NMR $\left(\mathrm{D}_{2} \mathrm{O}\right): \delta 1.77(\mathrm{~m}, 2 \mathrm{H}), 1.87(\mathrm{~m}, 2 \mathrm{H}), 2.37(\mathrm{~m}, 2 \mathrm{H}), 2.45(\mathrm{t}, J=7.3 \mathrm{~Hz}, 2 \mathrm{H}), 3.32$ $(\mathrm{m}, 2 \mathrm{H}), 3.36$ (ddd, $J=14.0,9.8$ and $6.2 \mathrm{~Hz}, 1 \mathrm{H}), 3.44$ (ddd, $J=14.0,9.6$ and $6.6 \mathrm{~Hz}, 1 \mathrm{H}$ ), $3.89(\mathrm{t}, J=6.2 \mathrm{~Hz}, 1 \mathrm{H}) ;{ }^{13} \mathrm{C} \mathrm{NMR}\left(\mathrm{D}_{2} \mathrm{O}\right): \delta 22.27,24.49,24.80,35.00,49.94,53.44,54.65$, 174.33, 179.86; HR-MS (FAB) calculated for $\mathrm{C}_{9} \mathrm{H}_{18} \mathrm{NO}_{6} \mathrm{~S}\left(\mathrm{MH}^{+}\right)$268.0840, found 268.0855.

(R)-5-(2-Amino-2-carboxy-ethylsulfanyl)-pentanoic acid (12)

The title compound was prepared from ethyl-6-bromo-pentanoate (29; $209 \mathrm{mg}, 1 \mathrm{mmole})$ according to Method A. The yield was $80 \mathrm{mg}(36 \%) .{ }^{1} \mathrm{H}$ NMR $\left(\mathrm{D}_{2} \mathrm{O}+\mathrm{NaOD}\right): \delta 1.58(\mathrm{~m}$, $2 \mathrm{H}), 1.62(\mathrm{~m}, 2 \mathrm{H}), 2.19(\mathrm{t}, J=7.2 \mathrm{~Hz}, 2 \mathrm{H}), 2.59(\mathrm{t}, J=7.1 \mathrm{~Hz}, 2 \mathrm{H}), 2.76(\mathrm{dd}, J=13.4$ and 6.8 $\mathrm{Hz}, 1 \mathrm{H}), 2.85(\mathrm{dd}, J=13.4$ and $5.2 \mathrm{~Hz}, 1 \mathrm{H}), 3.40(\mathrm{dd}, J=6.8$ and $5.2 \mathrm{~Hz}, 1 \mathrm{H}) ;{ }^{13} \mathrm{C}$ NMR $\left(\mathrm{D}_{2} \mathrm{O}+\mathrm{NaOD}\right): \delta 27.85,31.54,34.14,39.69,39.86,57.95,183.91,186.38 ;$ HR-MS (FAB) calculated for $\mathrm{C}_{8} \mathrm{H}_{16} \mathrm{NO}_{4} \mathrm{~S}\left(\mathrm{MH}^{+}\right)$222.0800, found 222.0804.

\section{(R,S)-2-(3-Amino-3-carboxy-propylsulfanyl)-benzoic acid (13)}

The title compound was prepared from 2-mercapto-benzoic acid (32; $106 \mathrm{mg}, 0.69 \mathrm{mmole})$ according to the Method B. The yield was $52 \mathrm{mg}(36 \%) .{ }^{1} \mathrm{H}$ NMR (DMSO): $\delta 2.09(\mathrm{~m}, 2 \mathrm{H}$ ), 3.02 (ddd, $J=13.0,9.3$ and $5.8 \mathrm{~Hz}, 1 \mathrm{H}), 3.08$ (ddd, $J=13.0,9.6$ and $6.4 \mathrm{~Hz}, 1 \mathrm{H}), 4.00(\mathrm{t}, J=$ $6.2 \mathrm{~Hz}, 2 \mathrm{H}), 7.24$ (ddd, $J=7.8,7.5$ and $0.9 \mathrm{~Hz}, 1 \mathrm{H}), 7.40(\mathrm{bd}, J=7.8 \mathrm{~Hz}, 1 \mathrm{H}), 7.54$ (ddd, $J=$ 7.8, 7.5 and $1.7 \mathrm{~Hz}, 1 \mathrm{H}), 7.89(\mathrm{dd}, J=7.8$ and $1.7 \mathrm{~Hz}, 1 \mathrm{H}), 8.30(\mathrm{~b}, 2 \mathrm{H}), 13.20(\mathrm{vb}, 1 \mathrm{H}) ;{ }^{13} \mathrm{C}$ NMR (DMSO): $\delta 26.64,29.28,51.74,124.38,125.55,128.67,131.26,132.58,139.86,167.62$, 170.69; HR-MS (FAB) calculated for $\mathrm{C}_{11} \mathrm{H}_{14} \mathrm{NO}_{4} \mathrm{~S}\left(\mathrm{MH}^{+}\right)$256.0644, found 256.0649.

\section{(R,S)-3-(3-Amino-3-carboxy-propylsulfanyl)-benzoic acid (14)}

The title compound was prepared from 3-mercapto-benzoic acid (33; $120 \mathrm{mg}, 0.78 \mathrm{mmole})$ according to the Method B. The yield was $46 \mathrm{mg}(28 \%) .{ }^{1} \mathrm{H}$ NMR (DMSO): $\delta 2.04(\mathrm{~m}, 2 \mathrm{H})$, $3.14(\mathrm{~m}, 2 \mathrm{H}), 3.93(\mathrm{t}, J=6.4 \mathrm{~Hz}, 1 \mathrm{H}), 7.47(\mathrm{t}, J=7.8 \mathrm{~Hz}, 1 \mathrm{H}), 7.59$ (ddd, $J=7.8,2.1$ and 1.1 $\mathrm{Hz}, 1 \mathrm{H}), 7.77$ (ddd, $J=7.8,1.6$ and $1.1 \mathrm{~Hz}, 1 \mathrm{H}), 7.85(\mathrm{dd}, J=2.1$ and $1.6 \mathrm{~Hz}, 1 \mathrm{H}) ; 8.30(\mathrm{~b}$, $2 \mathrm{H}$ ), $13.20(\mathrm{vb}, 1 \mathrm{H}) ;{ }^{13} \mathrm{C}$ NMR (DMSO): $\delta 28.06,29.91,51.57,127.04,128.91,129.62,131.96$, 132.53, 136.23, 166.96, 170.56; HR-MS (FAB) calculated for $\mathrm{C}_{11} \mathrm{H}_{14} \mathrm{NO}_{4} \mathrm{~S}\left(\mathrm{MH}^{+}\right)$256.0644, found 256.0651 .

\section{(R,S)-4-(3-Amino-3-carboxy-propylsulfanyl)-benzoic acid (15)}

The title compound was prepared from 4-mercapto-benzoic acid (34; $185 \mathrm{mg}, 1.2 \mathrm{mmole})$ according to the Method B. The yield was $47 \mathrm{mg}(19 \%) .{ }^{1} \mathrm{H}$ NMR (DMSO + AcOD): $\delta 1.99$ (m, 1H), $2.07(\mathrm{~m}, 1 \mathrm{H}), 3.14$ (ddd, $J=13.5,9.7$ and $5.7 \mathrm{~Hz}, 1 \mathrm{H}), 3.20$ (ddd, $J=13.5,9.7$ and $6.0 \mathrm{~Hz}, 1 \mathrm{H}), 3.61(\mathrm{t}, J=6.1 \mathrm{~Hz}, 1 \mathrm{H}), 7.39(\mathrm{~m}, 2 \mathrm{H}), 7.85(\mathrm{~m}, 2 \mathrm{H}) ;{ }^{13} \mathrm{C} \mathrm{NMR}$ (DMSO + AcOD): $\delta$ 27.17, 30.40, 52.62, 126.42 (2C), 127.59, 130.14 (2C), 142.83, 167.18, 170.52; HR-MS (FAB) calculated for $\mathrm{C}_{11} \mathrm{H}_{14} \mathrm{NO}_{4} \mathrm{~S}\left(\mathrm{MH}^{+}\right)$256.0644, found 256.0650 . 


\section{(R,S)-2-Amino-4-(4-carboxymethyl-benzylsulfanyl)-butyric acid (16)}

The title compound was prepared from (4-bromomethyl-phenyl)-acetic acid (35; $229 \mathrm{mg}, 1$ mmole) according to Method A. The yield was $43 \mathrm{mg}(15 \%) .{ }^{1} \mathrm{H} \mathrm{NMR}\left(\mathrm{DMSO}+\mathrm{D}_{2} \mathrm{O}\right): \delta$ $1.93(\mathrm{~m}, 1 \mathrm{H}), 2.03(\mathrm{~m}, 1 \mathrm{H}), 2.48(\mathrm{~m}, 2 \mathrm{H}), 3.52(\mathrm{~s}, 2 \mathrm{H}), 3.58(\mathrm{t}, J=6.0 \mathrm{~Hz}, 1 \mathrm{H}), 3.68(\mathrm{~s}, 2 \mathrm{H})$, $7.17(\mathrm{~m}, 2 \mathrm{H}), 7.23(\mathrm{~m}, 2 \mathrm{H}) ;{ }^{13} \mathrm{C}$ NMR (DMSO $\left.+\mathrm{D}_{2} \mathrm{O}\right): \delta 27.16,30.80,34.66,40.51,52.66$, 128.77 (2C), 129.48 (2C), 133.68, 136.92, 170.93, 173.56; HR-MS (FAB) calculated for $\mathrm{C}_{13} \mathrm{H}_{18} \mathrm{NO}_{4} \mathrm{~S}\left(\mathrm{MH}^{+}\right) 284.0878$, found 284.0899.

\section{(R,S)-4-Allylsulfanyl-2-amino-butyric acid (17)}

The title compound was prepared from 3-bromo-propene (36; $120 \mathrm{mg}, 1 \mathrm{mmole})$ according to Method A. The yield was $121 \mathrm{mg}(69 \%) .{ }^{1} \mathrm{H}$ NMR (DMSO): $\delta 1.99(\mathrm{~m}, 2 \mathrm{H}), 2.54(\mathrm{~m}, 2 \mathrm{H})$, 3.15 (ddd, $J=7.2,1.3$ and $0.9 \mathrm{~Hz}, 2 \mathrm{H}), 3.86(\mathrm{t}, J=6.3 \mathrm{~Hz}, 1 \mathrm{H}), 5.08(\mathrm{~m}, J=10.0,1.8,0.9$ and $0.9 \mathrm{~Hz}, 1 \mathrm{H}), 5.13(\mathrm{~m}, J=17.1,1.8,1.3$ and $1.3 \mathrm{~Hz}, 1 \mathrm{H}), 5.76(\mathrm{~m}, J=17.1,10.0,7.2$ and 7.2 $\mathrm{Hz}, 1 \mathrm{H}), 8.27$ (bs, $1 \mathrm{H}) ;{ }^{13} \mathrm{C}$ NMR (DMSO): $\delta 25.63,30.27,33.49,51.59,117.46,134.51$, 170.84; HR-MS (FAB) calculated for $\mathrm{C}_{7} \mathrm{H}_{14} \mathrm{NO}_{2} \mathrm{~S}\left(\mathrm{MH}^{+}\right)$176.0745, found 176.0749.

\section{(R,S)-2-Amino-4-methylsulfanylmethylsulfanyl-butyric acid (18)}

The title compound was prepared from chloro-methylsulfanyl-methane (37; $96 \mathrm{mg}, 1 \mathrm{mmole})$ according to Method A. The yield 14 was $4 \mathrm{mg}(2 \%) .{ }^{1} \mathrm{H}$ NMR (DMSO): $\delta 1.85(\mathrm{~m}, J=14.4$, 7.8, 7.8 and $7.0 \mathrm{~Hz}, 1 \mathrm{H}), 2.01(\mathrm{~m}, J=14.4,7.8,7.8$ and $5.4 \mathrm{~Hz}, 1 \mathrm{H}), 2.10(\mathrm{~s}, 3 \mathrm{H}), 2.68(\mathrm{t}, J=$ $7.8 \mathrm{~Hz}, 2 \mathrm{H}$ ), 3.36 (m, 1H), 3.73 (s, 2H), 7.86 (vb, 2H); ${ }^{13} \mathrm{C}$ NMR (DMSO): $\delta 14.19,26.89$, 30.93, 36.68, 52.99, 169.75; HR-MS (FAB) calculated for $\mathrm{C}_{6} \mathrm{H}_{14} \mathrm{NO}_{2} \mathrm{~S}_{2}\left(\mathrm{MH}^{+}\right)$196.0466, found 196.0429 .

\section{(R,S)-2-Amino-4-(2-carboxymethylsulfanyl-ethylsulfanyl)-butyric acid (19)}

Methyl-mercapto-acetate (1.485 mg, 14 mmoles) was added drop-wise, on ice and under argon atmosphere, to triethylamine $(1.413 \mathrm{~g}, 14 \mathrm{mmoles})$ in dichloroethane $(15 \mathrm{ml})$. After $18 \mathrm{~h}$ at room temperature, the reaction mixture was evaporated and the product, methyl-(2-chloroethylsulfanyl)-acetate (38), was purified on the column of silica gel using a linear gradient of ethyl acetate in toluene $(0-5 \%)$ with the yield of $1.1 \mathrm{~g}(47 \%)$. The quality of the product was verified with MS and NMR. The title compound (19) was prepared from methyl (2-chloroethylsulfanyl)-acetate (38, prepared as described above; $150 \mathrm{mg}, 0.89 \mathrm{mmole}$ ) according to Method A. The yield was $120 \mathrm{mg}(53 \%) .{ }^{1} \mathrm{H}$ NMR (DMSO): $\delta 1.89(\mathrm{~m}, 1 \mathrm{H}), 2.01(\mathrm{~m}, 1 \mathrm{H})$, $2.60(\mathrm{~m}, 2 \mathrm{H}), 2.70-2.80(\mathrm{~m}, 4 \mathrm{H}), 3.25(\mathrm{~d}, J=14.5 \mathrm{~Hz}, 1 \mathrm{H}), 3.28(\mathrm{~d}, J=14.5 \mathrm{~Hz}, 1 \mathrm{H}), 3.58$ (m, 1H); ${ }^{13} \mathrm{C}$ NMR (DMSO): $\delta 26.94,30.55,31.12$, 32.11, 33.65, 52.65, 170.74, 172.14; HRMS (FAB) calculated for $\mathrm{C}_{8} \mathrm{H}_{16} \mathrm{NO}_{4} \mathrm{~S}_{2}\left(\mathrm{MH}^{+}\right)$254.0521, found 254.0533 .

\section{(R,S)-2-Amino-4-(2-carboxymethylsulfinyl-ethylsulfanyl)-butyric acid (20)}

Methyl-(2-chloro-ethylsulfanyl)-acetate (38, prepared as described above; $0.336 \mathrm{~g}, 2$ mmoles) was oxidized with hydrochloric acid and hydrogen peroxide as described for compound $\mathbf{1 0}$ Yield $0.206 \mathrm{~g}(56 \%)$. The resulting (2-chloro-ethanesulfinyl)-acetic acid methyl ester (39; 0.17 $\mathrm{g}, 0.92 \mathrm{mmole}$ ) was reacted with $\mathrm{D}$, L-homocysteine according to Method A. The yield was 53 $\mathrm{mg}(21 \%) .{ }^{1} \mathrm{H}$ NMR $\left(\mathrm{D}_{2} \mathrm{O}\right): \delta 2.21(\mathrm{~m}, 1 \mathrm{H}), 2.30(\mathrm{~m}, 1 \mathrm{H}), 2.80(\mathrm{~m}, 2 \mathrm{H}), 2.98(\mathrm{~m}, 1 \mathrm{H}), 3.08$ $(\mathrm{m}, 1 \mathrm{H}), 3.30(\mathrm{~m}, 2 \mathrm{H}), 3.92(\mathrm{~d}, J=15.0 \mathrm{~Hz}, 1 \mathrm{H}), 4.04(\mathrm{~d}, J=15.0 \mathrm{~Hz}, 1 \mathrm{H}), 4.14(\mathrm{t}, J=6.4 \mathrm{~Hz}$, $1 \mathrm{H}) ;{ }^{13} \mathrm{C}$ NMR $\left(\mathrm{D}_{2} \mathrm{O}\right)$ : mixture of diastereoisomers $(1: 1)$ leads to doubling of some carbon signals (shown in brackets), $\delta 25.83$ (25.91), 28.71 (28.82), 31.72 (31.75), 52.67 (52.70), 54.40 (54.42), 57.38, 171.60, 174.54; HR-MS (FAB) calculated for $\mathrm{C}_{8} \mathrm{H}_{16} \mathrm{NO}_{5} \mathrm{~S}_{2}\left(\mathrm{MH}^{+}\right) 270.0470$, found 270.0466 . 


\section{(R,S)-2-Amino-4-(2-carboxy-ethyldisulfanyl)-butyric acid (21)}

D,L-homocysteine (5; $202 \mathrm{mg}, 1.5 \mathrm{mmole})$ and methyl-mercapto-acetate (178 mg, $1.5 \mathrm{mmole})$ were treated with hydrogen peroxide $(169 \mu \mathrm{l}, 1.65 \mathrm{mmole})$ dissolved in $20 \%$ aqueous ethanol $(12 \mathrm{ml})$ at room temperature overnight. The reaction mixture was applied to Dowex 50W $\left(\mathrm{H}^{+}\right)$, the resin was washed with water and the products eluted with $2.5 \%$ ammonia. After evaporation, the product was purified with RP-HPLC. The yield was $42 \mathrm{mg}(11 \%) .{ }^{1} \mathrm{H}$ NMR $\left(\mathrm{D}_{2} \mathrm{O}\right): \delta 2.32(\mathrm{~m}, J=14.8,7.5,7.0$ and $6.9 \mathrm{~Hz}, 1 \mathrm{H}), 2.40(\mathrm{~m}, J=14.8,7.5,7.5$ and $6.0 \mathrm{~Hz}$, $1 \mathrm{H}), 2.83(\mathrm{~m}, 2 \mathrm{H}), 2.87(\mathrm{~m}, 2 \mathrm{H}), 2.98(\mathrm{~m}, 2 \mathrm{H}), 4.16(\mathrm{dd}, J=6.9$ and $6.0 \mathrm{~Hz}, 1 \mathrm{H}) ;{ }^{13} \mathrm{C} \mathrm{NMR}$ $\left(\mathrm{D}_{2} \mathrm{O}\right): \delta 31.99,35.13,35.26,36.29,54.59,174.74,179.28$; HR-MS (FAB) calculated for $\mathrm{C}_{7} \mathrm{H}_{14} \mathrm{NO}_{4} \mathrm{~S}_{2}\left(\mathrm{MH}^{+}\right) 240.0364$, found 240.0370 .

\section{(R,S)-2-Amino-4-(4-phosphono-butylsulfanyl)-butyric acid (22)}

The reaction of diisopropyl-(4-bromo-butyl)-phosphonate ${ }^{37}$ (40; $0.3 \mathrm{~g}, 1$ mmole) with D,Lhomocysteine (5) according to Method A afforded (R,S)-2-amino-4-[4-(diisopropoxyphosphoryl)-butylsulfanyl]-butyrate in the yield of $0.164 \mathrm{~g} \mathrm{(46 \% ).}{ }^{1} \mathrm{H}$ NMR (DMSO): $\delta 1.227$ (d, $J=6.2 \mathrm{~Hz}, 6 \mathrm{H}), 1.230(\mathrm{~d}, J=6.2 \mathrm{~Hz}, 6 \mathrm{H}), 1.54(\mathrm{~m}, 2 \mathrm{H}), 1.59(\mathrm{~m}, 2 \mathrm{H}), 1.67(\mathrm{~m}, 2 \mathrm{H}), 2.01$ $(\mathrm{m}, 2 \mathrm{H}), 2.51(\mathrm{t}, J=7.0 \mathrm{~Hz}, 2 \mathrm{H}), 2.55(\mathrm{ddd}, J=13.5,9.1$ and $6.0 \mathrm{~Hz}, 1 \mathrm{H}), 2.62$ (ddd, $J=13.5$, 9.2 and $6.5 \mathrm{~Hz}, 1 \mathrm{H}), 3.99(\mathrm{bt}, J \sim 6 \mathrm{~Hz}, 1 \mathrm{H}), 4.53\left(\mathrm{dh},{ }^{3} J(\mathrm{H}, \mathrm{P})=8.0, J(\mathrm{H}, \mathrm{H})=6.2 \mathrm{~Hz}, 1 \mathrm{H}\right)$, $4.54(\mathrm{~h}, J=6.2 \mathrm{~Hz}, 1 \mathrm{H}), 8.28(\mathrm{~b}, 2 \mathrm{H}) ;{ }^{13} \mathrm{C}$ NMR (DMSO): $\delta 21.53\left(\mathrm{~d},{ }^{3} J(\mathrm{C}, \mathrm{P})=4.9 \mathrm{~Hz}\right), 23.98$ $\left(\mathrm{d},{ }^{3} J(\mathrm{C}, \mathrm{P})=4.4 \mathrm{~Hz}, 4 \mathrm{C}\right), 25.57\left(\mathrm{~d},{ }^{1} J(\mathrm{C}, \mathrm{P})=140.6 \mathrm{~Hz}\right), 26.40,29.52,30.19,30.33,51.24$, $69.22\left(\mathrm{~d},{ }^{2} J(\mathrm{C}, \mathrm{P})=6.3 \mathrm{~Hz}\right), 170.90$; HR-MS (FAB) calculated for $\mathrm{C}_{14} \mathrm{H}_{31} \mathrm{NO}_{5} \mathrm{PS}\left(\mathrm{MH}^{+}\right)$ 356.1661 , found 356.1651 . This compound $(0.156 \mathrm{~g}, 0.44 \mathrm{mmole})$ was treated with bromotrimethylsilane $(0.456 \mathrm{~g}, 3 \mathrm{mmoles})$ in dry DMF $(3 \mathrm{ml})$ under argon atmosphere at $50^{\circ}$ $\mathrm{C}$ for $2 \mathrm{~h}$. Then, $5 \mathrm{ml}$ of methanol was added and the reaction was warmed up at $50^{\circ} \mathrm{C}$ for an additional $\mathrm{h}$. The reaction mixture was evaporated and the residue was partioned between water and ethyl acetate. The water layer was evaporated to dryness and the product, compound $\mathbf{2 2}$, was purified by RP-HPLC. The yield was $76 \mathrm{mg}(64 \%) .{ }^{1} \mathrm{H}$ NMR $\left(\mathrm{D}_{2} \mathrm{O}\right): \delta 1.61-1.89(\mathrm{~m}, 6 \mathrm{H})$, $2.18(\mathrm{~m}, 1 \mathrm{H}), 2.28(\mathrm{~m}, 1 \mathrm{H}), 2.62(\mathrm{t}, J=7.0 \mathrm{~Hz}, 2 \mathrm{H}) ; 2.72(\mathrm{t}, J=7.5 \mathrm{~Hz}, 2 \mathrm{H}), 4.16(\mathrm{dd}, J=6.7$ and $6.0 \mathrm{~Hz}, 1 \mathrm{H}) ;{ }^{13} \mathrm{C}$ NMR $\left(\mathrm{D}_{2} \mathrm{O}\right): \delta 23.63\left(\mathrm{~d},{ }^{3} J(\mathrm{C}, \mathrm{P})=4.7 \mathrm{~Hz}\right), 28.21\left(\mathrm{~d},{ }^{1} J(\mathrm{C}, \mathrm{P})=134.2\right.$ $\mathrm{Hz}), 28.47,31.59\left(\mathrm{~d},{ }^{2} J(\mathrm{C}, \mathrm{P})=16.6 \mathrm{~Hz}\right), 31.75,32.31,54.29,174.30$; HR-MS (FAB) calculated for $\mathrm{C}_{8} \mathrm{H}_{19} \mathrm{NO}_{5} \mathrm{PS}\left(\mathrm{MH}^{+}\right)$272.0722, found 272.0734.

\section{(R,S)-2-Amino-4-(2-phosphonomethoxy-ethylsulfanyl)-butyrate (23)}

The reaction of diisopropyl-(2-chloro-ethoxymethyl)-phosphonate ${ }^{38}$ (41; $\left.0.259 \mathrm{~g}, 1 \mathrm{mmole}\right)$ with D,L-homocysteine (5) according to Method A afforded (R,S)-2-amino-4-[2-

(diisopropoxy-phosphorylmethoxy)-ethylsulfanyl]-butyrate in the yield of $21 \mathrm{mg}(8 \%) .{ }^{1} \mathrm{H}$ NMR (DMSO): $\delta 1.97(\mathrm{~m}, 1 \mathrm{H}), 2.04(\mathrm{~m}, 1 \mathrm{H}), 2.64(\mathrm{~m}, 2 \mathrm{H}), 2.68(\mathrm{t}, J=6.6 \mathrm{~Hz}, 2 \mathrm{H}), 3.66(\mathrm{t}$, $J=6.6 \mathrm{~Hz}, 2 \mathrm{H}), 3.76(\mathrm{~d}, J(\mathrm{H}, \mathrm{P})=8.4 \mathrm{~Hz}, 2 \mathrm{H}), 3.92(\mathrm{dd}, J=6.6$ and $5.9 \mathrm{~Hz}, 1 \mathrm{H}), 4.60(\mathrm{dh}, \mathrm{J}$ $(\mathrm{H}, \mathrm{P})=7.7$ and $J(\mathrm{H}, \mathrm{H})=6.2 \mathrm{~Hz}, 2 \mathrm{H}), 8.22(\mathrm{vb}, 2 \mathrm{H}) ;{ }^{13} \mathrm{C}$ NMR (DMSO): $\delta 23.93\left(\mathrm{~d},{ }^{3} J(\mathrm{C}, \mathrm{P})\right.$ $=4.5 \mathrm{~Hz}, 2 \mathrm{C}), 24.03\left(\mathrm{~d},{ }^{3} J(\mathrm{C}, \mathrm{P})=3.8 \mathrm{~Hz}, 2 \mathrm{C}\right), 27.04,30.06,30.52,51.35,64.77\left(\mathrm{~d},{ }^{1} J(\mathrm{C}, \mathrm{P})\right.$ $=164.9 \mathrm{~Hz}), 70.39\left(\mathrm{~d},{ }^{2} J(\mathrm{C}, \mathrm{P})=6.3 \mathrm{~Hz}\right), 72.08\left(\mathrm{~d},{ }^{3} J(\mathrm{C}, \mathrm{P})=12.1 \mathrm{~Hz}\right), 170.85$; HR-MS (FAB) calculated for $\mathrm{C}_{13} \mathrm{H}_{29} \mathrm{NO}_{6} \mathrm{PS}\left(\mathrm{MH}^{+}\right) 358.1453$, found 358.1434. This compound (20 mg, 56 $\mu$ moles) was treated with bromotrimethylsilane $(0.106 \mathrm{~g}, 0.7 \mathrm{mmole})$ in dry DMF $(1 \mathrm{ml})$ under argon atmosphere at room temperature overnight. The reaction mixture was concentrated in vacuo and the residue was co-evaporated with $10 \%$ triethylamine in acetonitrile $(3 \times 1 \mathrm{ml})$ and then with water. The product $\mathbf{2 3}$ was purified by RP-HPLC. The yield was $15 \mathrm{mg}(31 \%) .{ }^{1} \mathrm{H}$ NMR $\left(\mathrm{D}_{2} \mathrm{O}\right): \delta 2.21(\mathrm{~m}, 1 \mathrm{H}), 2.30(\mathrm{~m}, 1 \mathrm{H}), 2.78(\mathrm{t}, J=7.5 \mathrm{~Hz}, 2 \mathrm{H}) ; 2.82(\mathrm{t}, J=6.1 \mathrm{~Hz}, 2 \mathrm{H})$, $3.70(\mathrm{~d}, J(\mathrm{H}, \mathrm{P})=8.8 \mathrm{~Hz}, 2 \mathrm{H}), 3.79(\mathrm{t}, J=6.0 \mathrm{~Hz}, 2 \mathrm{H}), 4.16(\mathrm{dd}, J=6.6$ and $6.0 \mathrm{~Hz}, 1 \mathrm{H}) ;{ }^{13} \mathrm{C}$ NMR $\left(\mathrm{D}_{2} \mathrm{O}\right): \delta 27.60,30.43,31.03,52.92,67.08\left(\mathrm{~d},{ }^{1} J(\mathrm{C}, \mathrm{P})=167.1 \mathrm{~Hz}\right), 72.59\left(\mathrm{~d},{ }^{3} J(\mathrm{C}, \mathrm{P})=\right.$ $10.8 \mathrm{~Hz}), 172.94$; HR-MS (FAB) calculated for $\mathrm{C}_{7} \mathrm{H}_{17} \mathrm{NO}_{6} \mathrm{PS}\left(\mathrm{MH}^{+}\right) 274.0516$, found 274.0523 


\section{(R,S)-2-Amino-4-[(phosphonomethyl-carbamoyl)-methylsulfanyl]-butyrate (24)}

The reaction of diethyl-[(2-chloro-acetylamino)-methyl]-phosphonate ${ }^{39}$ (42; $0.125 \mathrm{~g}, 0.51$ mmole) with D,L-homocysteine (5) according to Method A afforded ( $R, S)$-2-amino-4$\{[($ diethoxy-phosphorylmethyl)-carbamoyl]-methylsulfanyl $\}$-butyrate in the yield of $92 \mathrm{mg}$ (52\%). ${ }^{1} \mathrm{H}$ NMR (DMSO): $\delta 1.23(\mathrm{t}, J=7.0 \mathrm{~Hz}, 6 \mathrm{H}), 2.00(\mathrm{~m}, 1 \mathrm{H}), 2.08(\mathrm{~m}, 1 \mathrm{H}), 2.68$ (ddd, $J=13.5,8.4$ and $6.2 \mathrm{~Hz}, 1 \mathrm{H}), 2.73(\mathrm{ddd}, J=13.5,8.6$ and $6.8 \mathrm{~Hz}, 1 \mathrm{H}), 3.19(\mathrm{~s}, 2 \mathrm{H}), 3.58(\mathrm{dd}$, $J(\mathrm{H}, \mathrm{P})=11.6$ and $J(\mathrm{H}, \mathrm{H})=6.0 \mathrm{~Hz}, 2 \mathrm{H}), 3.96(\mathrm{bdd}, J=6.8$ and $6.2 \mathrm{~Hz}, 1 \mathrm{H}), 4.02(\mathrm{~m}, 4 \mathrm{H}), 8.30$ $(\mathrm{vb}, 2 \mathrm{H}), 8.43$ (bt, $J=6.0 \mathrm{~Hz}, 1 \mathrm{H}) ;{ }^{13} \mathrm{C} \mathrm{NMR}$ (DMSO): $\delta 16.41\left(\mathrm{~d},{ }^{3} J(\mathrm{C}, \mathrm{P})=5.4 \mathrm{~Hz}, 2 \mathrm{C}\right.$ ), 27.37, 29.92, 33.68, $34.31\left(\mathrm{~d},{ }^{1} J(\mathrm{C}, \mathrm{P})=157.1 \mathrm{~Hz}\right), 51.20,62.00\left(\mathrm{~d},{ }^{2} J(\mathrm{C}, \mathrm{P})=5.9 \mathrm{~Hz}, 2 \mathrm{C}\right)$, $169.17\left(\mathrm{~d},{ }^{3} J(\mathrm{C}, \mathrm{P})=4.3 \mathrm{~Hz}\right), 170.87$; HR-MS $(\mathrm{FAB})$ calculated for $\mathrm{C}_{11} \mathrm{H}_{24} \mathrm{~N}_{2} \mathrm{O}_{6} \mathrm{PS}\left(\mathrm{MH}^{+}\right)$ 343.11093, found 343.1097. This compound (19 mg, $55 \mu$ moles) was treated with bromotrimethylsilane $(61 \mathrm{mg}, 450 \mu$ moles $)$ in dry DMF $(1 \mathrm{ml})$ under argon atmosphere at $50^{\circ}$ $\mathrm{C}$ overnight. The reaction mixture was concentrated in vacuo and the residue was co-evaporated with $10 \%$ triethylamine in acetonitrile $(3 \times 1 \mathrm{ml})$ and then with water. The product $\mathbf{2 4}$ was purified by RP-HPLC. The yield was $10 \mathrm{mg}(62 \%) .{ }^{1} \mathrm{H}$ NMR $\left(\mathrm{D}_{2} \mathrm{O}\right): \delta 2.18(\mathrm{~m}, 1 \mathrm{H}), 2.27(\mathrm{~m}$, $1 \mathrm{H}), 2.76(\mathrm{~m}, 2 \mathrm{H}), 3.36(\mathrm{~d}, J(\mathrm{H}, \mathrm{P})=0.6 \mathrm{~Hz}, 2 \mathrm{H}) ; 3.50(\mathrm{~d}, J(\mathrm{H}, \mathrm{P})=12.4 \mathrm{~Hz}, 2 \mathrm{H}), 4.12(\mathrm{t}, J=$ $6.4 \mathrm{~Hz}, 1 \mathrm{H}) ;{ }^{13} \mathrm{C}$ NMR $\left(\mathrm{D}_{2} \mathrm{O}\right): \delta 28.11,30.23,35.58,38.26\left(\mathrm{~d},{ }^{1} J(\mathrm{C}, \mathrm{P})=171.5 \mathrm{~Hz}\right), 52.92$, 172.58, 172.77; HR-MS (FAB) calculated for $\mathrm{C}_{7} \mathrm{H}_{16} \mathrm{~N}_{2} \mathrm{O}_{6} \mathrm{PS}\left(\mathrm{MH}^{+}\right) 287.0467$, found 287.0459 .

In a parallel experiment, $(R, S)$-2-amino-4-\{[(diethoxy-phosphorylmethyl)-carbamoyl]methylsulfanyl $\}$-butyrate $(19 \mathrm{mg}, 55 \mu$ moles $)$ was treated with bromo trimethylsilane by the same manner as described above for compound 24. However, after completing of the deprotection, the reaction mixture was evaporated to dryness and then warmed up at $50^{\circ} \mathrm{C}$ for $1 \mathrm{~h}$ with methanol $(5 \mathrm{ml})$. After evaporation, the product, methyl $(R, S)$-2-amino-4-

[(phosphonomethyl-carbamoyl)-methylsulfanyl]-butyric acid ester (25), was purified by RPHPLC. The yield was $5 \mathrm{mg}(29 \%) .{ }^{1} \mathrm{H}$ NMR $\left(\mathrm{D}_{2} \mathrm{O}\right): \delta 2.21(\mathrm{~m}, 1 \mathrm{H}), 2.31(\mathrm{~m}, 1 \mathrm{H}), 2.78(\mathrm{~m}$, $2 \mathrm{H}), 3.36(\mathrm{~s}, 2 \mathrm{H}), 3.51(\mathrm{~d}, J(\mathrm{H}, \mathrm{P})=12.4 \mathrm{~Hz}, 2 \mathrm{H}), 3.86(\mathrm{~s}, 3 \mathrm{H}), 4.30(\mathrm{t}, J=6.5 \mathrm{~Hz}, 1 \mathrm{H}) ;{ }^{13} \mathrm{C}$ $\operatorname{NMR}\left(\mathrm{D}_{2} \mathrm{O}\right): \delta 29.52,31.43,37.05,39.76\left(\mathrm{~d},{ }^{1} J(\mathrm{C}, \mathrm{P})=146.5 \mathrm{~Hz}\right), 53.76,55.82,172.60,174.30$; MS (FAB) calculated for $\mathrm{C}_{8} \mathrm{H}_{18} \mathrm{~N}_{2} \mathrm{O}_{6} \mathrm{PS}\left(\mathrm{MH}^{+}\right) 301.05$, found 301.00 .

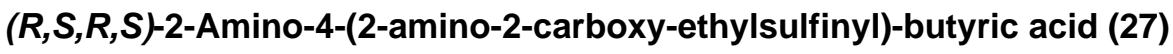

This oxidized derivative was prepared starting from commercial cystathionine (26; $0.1 \mathrm{mg}$, 0.45 mmoles) using the same procedure as for compound $\mathbf{1 0}$. The yield was $67 \mathrm{mg}(63 \%)$. The presence of four diastereoisomers leads to the observation up to four signals for individual hydrogens and carbon atoms. ${ }^{1} \mathrm{H}$ NMR $\left(\mathrm{D}_{2} \mathrm{O}\right): \delta 2.35-2.51(\mathrm{~m}, 2 \mathrm{H}), 3.09-3.33(\mathrm{~m}, 2 \mathrm{H}), 3.51-$ $4.03(\mathrm{~m}, 2 \mathrm{H}), 4.15-4.20(\mathrm{~m}, 1 \mathrm{H}), 4.43-4.47(\mathrm{~m}, 1 \mathrm{H}) ;{ }^{13} \mathrm{C} \mathrm{NMR}\left(\mathrm{D}_{2} \mathrm{O}\right): \delta 23.83,23.89,24.05$ and $24.10\left(\mathrm{CH}_{2}\right), 47.66,47.77,48.28$ and $48.38\left(\mathrm{~S}^{\left.-\mathrm{CH}_{2}-\right)}, 50.83,51.14,51.18\right.$ and 52.61 $\left(\mathrm{CH}_{2}-\mathrm{S}\right), 50.00$ and $50.45(\mathrm{CH}-\mathrm{N}), 52.61$ and $52.76(\mathrm{CH}-\mathrm{N}), 171.00,171.99$; HR-MS (FAB) calculated for $\mathrm{C}_{7} \mathrm{H}_{15} \mathrm{~N}_{2} \mathrm{O}_{5} \mathrm{~S}\left(\mathrm{MH}^{+}\right)$239.0702, found 239.0694 .

\section{BHMT Inhibition Assays}

Human recombinant BHMT was prepared as described previously ${ }^{3} \mathrm{~N}$-methyl- ${ }^{14} \mathrm{C}$-betaine $(57$ $\mathrm{mCi} / \mathrm{mmol}$ ) was prepared and supplied by Moravek Biochemicals (Brea, CA). Compounds were tested for their ability to inhibit BHMT activity using an assay procedure we have described previously in detail ${ }^{40}$ with only several modifications. Briefly, D,L-homocysteine was freshly prepared by dissolving D,L-homocysteine thiolactone hydrochloride $(15.4 \mathrm{mg})$ in $400 \mu \mathrm{l}$ of $2 \mathrm{M} \mathrm{NaOH}$. The solution was allowed to stand for $5 \mathrm{~min}$ at room temperature. The solution was then neutralized by the addition of $600 \mu \mathrm{l}$ of a saturated solution of $\mathrm{KH}_{2} \mathrm{PO}_{4}$ and immediately used in BHMT assay. 
The standard BHMT assay (500 $\mu \mathrm{l})$ used to determine the percent inhibition contained $0.2 \mu \mathrm{M}$ BHMT, different concentrations of inhibitor $(20 \mu \mathrm{M}$ or $1 \mu \mathrm{M}), 100 \mu \mathrm{M}$ D,L-homocysteine, $250 \mu \mathrm{M}$ betaine $(0.05 \mu \mathrm{Ci}), 10 \mathrm{mM} \beta$-mercaptoethanol and $50 \mathrm{mM}$ K-phosphate buffer $\mathrm{pH}$ 7.5. Human recombinant BHMT was first mixed with inhibitor(s), then the substrates were added and the mixture incubated at $37^{\circ} \mathrm{C}$ for 30 minutes. The reaction was stopped by transferring the reaction tubes into ice water and by adding $2.5 \mathrm{ml}$ of ice-cold water. The samples were applied to a Dowex $1 \times 4$ (200-400 mesh) and the non-reacted betaine was washed from the column with water. Dimethylglycine and methionine were eluted into scintillation vials with $1.5 \mathrm{ml}$ of $1.5 \mathrm{M} \mathrm{HCl}$ and then $10 \mathrm{ml}$ of scintillation mixture were added into each vial and counted. Blanks contained all the reaction components except enzyme and their values were subtracted from the sample values. All samples were assayed in triplicates and results (reproducible within $\pm 15 \%$ ) are expressed relative (\%) to a sample containing no inhibitor.

Inhibition curves for the determination of $\mathrm{IC}_{50}$ values were measured using the conditions described above except the concentrations of substrates used were $1 \mathrm{mM} \mathrm{D,L-homocysteine}$ and $2 \mathrm{mM}$ betaine $(0.15 \mu \mathrm{Ci})$. The inhibition at ten different inhibitor concentrations was determined for each curve. The data were analyzed by nonlinear regression fit using program GraphPad Prism3.02.

The apparent inhibition constant $\left(K_{\mathrm{i}}^{\text {app }}\right.$, cit. $\left.{ }^{41-43}\right)$ of inhibitor 2 towards betaine was measured at fixed concentration of D,L-homocysteine $(100 \mu \mathrm{M})$ and varied concentrations of betaine $(0.5,1,2$ and $4 \mathrm{mM})$ and inhibitor $(0,15,25,50,75$ and $100 \mathrm{nM})$. The reaction proceeded in a total volume of $250 \mu \mathrm{l}$ and contained $15 \mathrm{nM}$ BHMT and $1 \mu \mathrm{Ci}$ of ${ }^{14} \mathrm{C}$-betaine. The enzyme was pre-incubated with inhibitor for $15 \mathrm{~min}$ at room temperature, and then the substrates were added and the reaction was allowed to proceed for $1 \mathrm{~h}$ at $37^{\circ} \mathrm{C}$. The data were analyzed by Dixon plot. ${ }^{44}$

All points for determination of $\mathrm{IC}_{50}$ 's or $K_{\mathrm{i}}^{\text {app's }}$ were measured in duplicates and the values from 3 different assays are reproducible within $\pm 10 \%$.

\section{Supplementary Material}

Refer to Web version on PubMed Central for supplementary material.

\section{Acknowledgement}

This work was supported by a grant from the Grant Agency of the Academy of Sciences of the Czech Republic (A4055302, J.J.), Research Project of the Academy of Sciences of the Czech Republic (Z40550506, J.J.) and by grants from the National Institutes of Health (DK52501, T.A.G.) and the Illinois Agricultural Research Station (50-352,

T.A.G.) and by NIH Research Grant funded by the Fogarty International Center (R01 TW0052501, T.A.G. and J.J.). We thank to Dr. Vaclav Kasicka (IOCB, Prague) for performing capillary electrophoreses.

\section{References}

1. Finkelstein JD, Harris BJ, Kyle WE. Methionine metabolism in mammals: kinetic study of betainehomocysteine methyltransferase. Arch. Biochem. Biophys 1972;153:320-324. [PubMed: 4650615]

2. Millian NS, Garrow TA. Human betaine-homocysteine methyltransferase is a zinc metalloenzyme. Arch. Biochem. Biophys 1998;356:93-98. [PubMed: 9681996]

3. Breksa AP III, Garrow TA. Recombinant human liver betaine-homocysteine S-methyltransferase: identification of three cysteine residues critical for zinc binding. Biochemistry 1999;38:13991-13998. [PubMed: 10529246]

4. Evans JC, Huddler DP, Jiracek J, Castro C, Millian NS, Garrow TA, Ludwig ML. Betainehomocysteine methyltransferase. Zinc in a distorted barrel. Structure 2002;10:1159-1071. [PubMed: 12220488] 
5. Gonzalez B, Pajares MA, Martinez-Ripoll M, Blundell TL, Sanz-Aparicio J. Crystal structure of rat liver betaine homocysteine S-methyltransferase reveals new oligomerization features and conformational changes upon substrate binding. J. Mol.Biol 2004;338:771-782. [PubMed: 15099744]

6. Peariso K, Goulding CW, Huang S, Matthews RG, Penner-Hahn JE. Characterization of the zinc binding site in methionine synthase enzymes of Escherichia coli: The role of zinc in the methylation of homocysteine. J. Am. Chem. Soc 1998;120:8410-8416.

7. Peariso K, Zhou ZS, Smith AE, Matthews RG, Penner-Hahn JE. Characterization of the zinc sites in cobalamin-independent and cobalamin-dependent methionine synthase using zinc and selenium X-ray absorption spectroscopy. Biochemistry 2001;40:987-993. [PubMed: 11170420]

8. Szegedi SS, Garrow TA. Oligomerization is required for betaine-homocysteine S-methyltransferase function. Arch. Biochem. Biophys 2004;426:32-42. [PubMed: 15130780]

9. McKeever MP, Weir DG, Molloy A, Scott JM. Betaine-homocysteine methyltransferase: organ distribution in man, pig and rat and subcellular distribution in the rat. Clin. Sci. (Colch. ) 1991;81:551556. [PubMed: 1657504]

10. Kempson SA, Montrose MH. Osmotic regulation of renal betaine transport: transcription and beyond. Pflugers Arch 2004;449:227-234. [PubMed: 15452713]

11. Wettstein M, Weik C, Holneicher C, Häussinger D. Betaine as an osmolyte in rat liver: metabolism and cell-to-cell interactions. Hepatology 1998;27:787-793. [PubMed: 9500708]

12. Haussinger D. Neural control of hepatic osmolytes and parenchymal cell hydration. Anat. Rec. A Discov. Mol. Cell Evol. Biol 2004;280:893-900. [PubMed: 15382012]

13. Delgado-Reyes CV, Garrow TA. High sodium chloride intake decreases betaine-homocysteine methyltransferase expression in guinea pig liver and kidney. Am. J. Physiol. Regul. Integr. Comp. Physiol 2005;288:R182-R187. [PubMed: 15331385]

14. Refsum H, Ueland PM, Nygard O, Vollset SE. Homocysteine and cardiovascular disease. Annu. Rev. Med 1998;49:31-62. [PubMed: 9509248]

15. Homocysteine Studies Collaboration. Homocysteine and risk of ischemic heart disease and stroke: a meta-analysis. JAMA 2002;288:2015-2022. [PubMed: 12387654]

16. Ray JG. Meta-analysis of hyperhomocysteinemia as a risk factor for venous thromboem bolic disease. Arch. Intern. Med 1998;158:2101-2106. [PubMed: 9801176]

17. Vollset SE, Refsum H, Irgens LM, Emblem BM, Tverdal A, Gjessing HK, Monsen AL, Ueland PM. Plasma total homocysteine, pregnancy complications, and adverse pregnancy outcomes: the Hordaland homocysteine study. Am. J. Clin. Nutr 2000;71:962-968. [PubMed: 10731504]

18. Ray JG, Laskin CA. Folic acid and homocyst(e)ine metabolic defects and the risk of placental abruption, pre-eclampsia and spontaneous pregnancy loss: A systematic review. Placenta 1999;20:519-529. [PubMed: 10452905]

19. Bottiglieri T. Folate, vitamin B-12, and neuropsychiatric disorders. Nutr. Rev 1996;54:382-390. [PubMed: 9155210]

20. Seshadri S, Beiser A, Selhub J, Jacques PF, Rosenberg IH, D'Agostino RB, Wilson PW, Wolf PA. Plasma homocysteine as a risk factor for dementia and Alzheimer's disease. N. Engl. J. Med 2002;346:476-483. [PubMed: 11844848]

21. Chauveau P, Chadefaux B, Coude M, Aupetit J, Hannedouche T, Kamoun P, Jungers P. Hyperhomocysteinemia, a risk factor for atherosclerosis in chronic uremic patients. Kidney Int. Suppl 1993;41:S72-S77. [PubMed: 8320950]

22. Finkelstein JD, Martin JJ. Methionine metabolism in mammals. Distribution of homocysteine between competing pathways. J. Biol. Chem 1984;259:9508-9513. [PubMed: 6746658]

23. Mato JM, Corrales FJ, Lu SC, Avila MA. S-adenosylmethionine: a control switch that regulates liver function. Faseb J 2002;16:15-26. [PubMed: 11772932]

24. Duranton B, Freund JN, Galluser M, Schleiffer R, Gosse F, Bergmann C, Hasselmann R, Raul F. Promotion of intestinal carcinogenesis by dietary methionine. Carcinogenesis 1999;20:493-497. [PubMed: 10190567]

25. Pavillard V, Nicolaou A, Double JA, Phillips RM. Methionine dependence of tumours: A biochemical strategy for optimizing paclitaxel chemosensitivity in vitro. Biochem. Pharmacol 2006;71:772-778. [PubMed: 16414026] 
26. Mosharov E, Cranford MR, Banerjee R. The quantitatively important relationship between homocysteine metabolism and glutathione synthesis by the transsulfuration pathway and its regulation by redox changes. Biochemistry 2000;39:13005-13011. [PubMed: 11041866]

27. Awad WM Jr, Whitney PL, Skiba WE, Mangum JH, Wells MS. Evidence for direct methyl transfer in betaine: homocysteine $S$-methyl- transferase. J. Biol. Chem 1983;258:12790-12792. [PubMed: 6630207]

28. Castro C, Gratson AA, Evans JC, Jiracek J, Collinsova M, Ludwig ML, Garrow TA. Dissecting the catalytic mechanism of betaine-homocysteine $S$-methyltransferase by use of intrinsic tryptophan fluorescence and site-directed mutagenesis. Biochemistry 2004;43:5341-5351. [PubMed: 15122900]

29. Lee KH, Cava M, Amiri P, Ottoboni T, Lindquist RN. Betaine:homocysteine methyltransferase from rat liver: Purification and inhibition by a boronic acid substrate analog. Arch. Biochem. Biophys 1992;292:77-86. [PubMed: 1370132]

30. Collinsova M, Castro C, Garrow TA, Yiotakis A, Dive V, Jiracek J. Combining combinatorial chemistry and affinity chromatography: highly selective inhibitors of human betaine:homocysteine $S$-methyltransferase. Chem. Biol 2003;10:113-122. [PubMed: 12618183]

31. Koval D, Kasicka V, Jiracek J, Collinsova M. Separation of diastereomers of phosphinic pseudopeptides by capillary zone electrophoresis and reverse phase high-performance liquid chromatography. J. Sep. Sci 2003;26:653-660.

32. Koval D, Kasicka V, Jiracek J, Collinsova M. Physicochemical characterization of phosphinic pseudopeptides by capillary zone electrophoresis in highly acid background electrolytes. Electrophoresis 2003;24:774-781. [PubMed: 12627437]

33. Koval D, Kasicka V, Jiracek J, Collinsova M, Garrow TA. Determination of dissociation constant of phosphinate group in phosphinic pseudopeptides by capillary zone electrophoresis. J. Chromatogr. B 2002;770:145-154.

34. Koval D, Kasicka V, Jiracek J, Collinsova M, Garrow TA. Analysis and characterization of phosphinic pseudopeptides by capillary zone electrophoresis. Electrophoresis 2002;23:215-222. [PubMed: 11840526]

35. Bradford MM. A rapid and sensitive method for the quantitation of microgram quantities of protein utilizing the principle of protein-dye binding. Anal. Biochem 1976;72:248-254. [PubMed: 942051]

36. Farrington GK, Kumar A, Wedler FC. Design and synthesis of phosphonate inhibitors of glutamine synthetase. J. Med. Chem 1987;30:2062-2067. [PubMed: 2889829]

37. Viornery C, Pechy P, Boegli M, Aronsson BO, Descouts P, Gratzel M. Synthesis of new polyphosphonic acids. Phosphorus Sulfur Silicon Relat. Elem 2002;177:231-241.

38. Rejman D, Masojidkova M, De Clercq E, Rosenberg I. 2 '-C-alkoxy and 2 '-C-aryloxy derivatives of $N$-(2-phosphonomethoxyethyl)purines and -pyrimidines: Synthesis and biological activity. Nucleosides Nucleotides \& Nucleic Acids 2001;20:1497-1522.

39. Arbuzov BA, Vinogradova VS, Novoselskaja AD. Reaction of $N$-hydroxymethylchloroacetamide with triethyl phosphite and some dialkyl chlorophosphites. J. Gen. Chem. USSR (Engl. Transl. ) 1967;37:2061-2065.

40. Garrow TA. Purification, kinetic properties, and cDNA cloning of mammalian betaine-homocysteine methyltransferase. J. Biol. Chem 1996;271:22831-22838. [PubMed: 8798461]

41. Todhunter, JA. Reversible Enzyme Inhibition. In: Purich, DL., editor. Enzyme Kinetics and Mechanism. New York: Academic Press; 1979. p. 383-411.

42. Min K-L, Steghens J-P, Henry R, Doutheau A, Collombel C. N-Dibenzylhospho-N'-3-(2,6dichlorophenyl)propyl-guanidine is a bisubstrate-analog for creatine kinase. Biochim. Biophys. Acta 1997;1342:83-89. [PubMed: 9366273]

43. Segel, IH. Enzyme Kinetics. Behaviour and Analysis of Rapid Equilibrium and Steady-State Enzyme Systems. New York: John Wiley \& Sons, Inc.; 1993.

44. Dixon M. The graphical determination of $K_{\mathrm{m}}$ and $K_{\mathrm{i}}$. Biochem. J 1972;129:197-202. [PubMed: 4630451] 


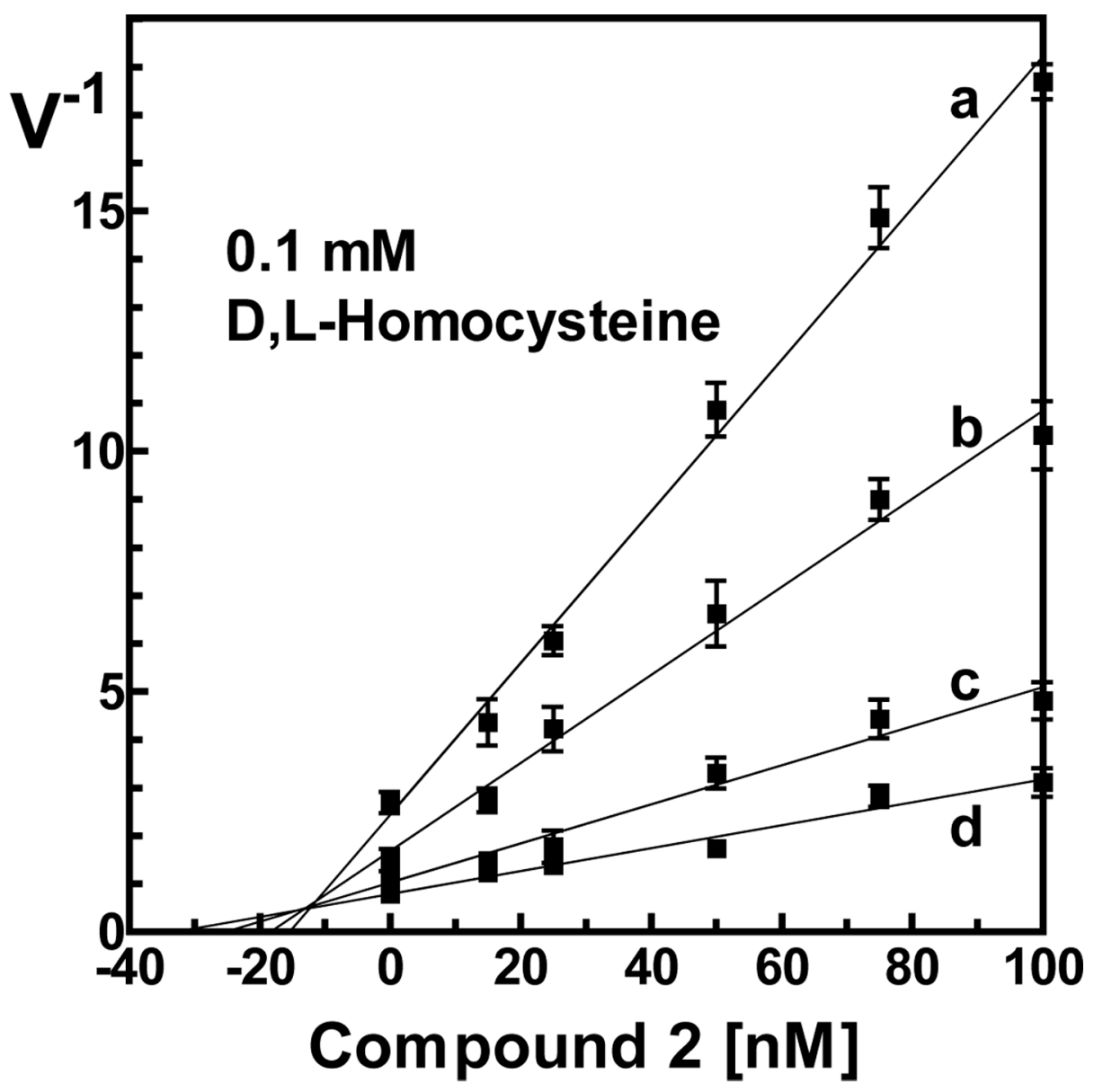

Figure 1.

Determination of $K_{\mathrm{i}}^{\mathrm{app}}$ of inhibitor $\mathbf{2}$ for human BHMT towards betaine. The curves were measured at fixed concentration of D,L-homocysteine $(100 \mu \mathrm{M})$ and four different concentrations of betaine (a, $0.5 \mathrm{mM} ; \mathrm{b}, 1 \mathrm{mM} ; \mathrm{c}, 2 \mathrm{mM} ; \mathrm{d}, 4 \mathrm{mM}$ ). The intersection point of curves gives $K_{\mathrm{i}}^{\text {app }}$ of about $12.0 \pm 0.9 \mathrm{nM}$. For details see Experimental. 
Table 1

Inhibition (relative) of human BHMT by $S$-substituted derivatives of homocysteine. The percentage inhibition of each compound was determined at 20 and $1 \mu \mathrm{M}$. See Experimental for details.

\begin{tabular}{|c|c|c|c|c|}
\hline & \multirow[t]{2}{*}{ Compound } & \multicolumn{2}{|c|}{$\begin{array}{c}\text { \% of Inhibition }{ }^{a}(0.25 \mathrm{mM} \\
\text { betaine, } 0.1 \mathrm{mM} \mathrm{D,L-} \\
\text { homocysteine })\end{array}$} & \multirow[t]{2}{*}{$\begin{array}{c}\mathrm{IC}_{50}(\mu \mathrm{M}) b(2 \mathrm{mM} \\
\text { betaine, } 1 \mathrm{mM} \\
\text { D,L- } \\
\text { homocysteine })\end{array}$} \\
\hline & & $20 \mu \mathrm{M}$ & $1 \mu \mathrm{M}$ & \\
\hline 2 & & 100 & 98.3 & 0.087 \\
\hline 8 & & 20.1 & nd & nd \\
\hline 9 & & 100 & 99.9 & 0.2 \\
\hline 10 & & 97.3 & 67.8 & 5 \\
\hline 11 & 0 & 28.8 & nd & nd \\
\hline 12 & & 0 & nd & nd \\
\hline 13 & & 42.5 & nd & nd \\
\hline 14 & & 12.8 & nd & nd \\
\hline 15 & & 98.6 & 84.8 & 7 \\
\hline 16 & & 10.1 & nd & nd \\
\hline 17 & & 0 & nd & nd \\
\hline 18 & & 20.5 & nd & nd \\
\hline
\end{tabular}




\begin{tabular}{|c|c|c|c|c|}
\hline & \multirow[t]{2}{*}{ Compound } & \multicolumn{2}{|c|}{$\begin{array}{c}\% \text { of Inhibition }{ }^{a}(0.25 \mathrm{mM} \\
\text { betaine, } 0.1 \mathrm{mM} \mathrm{D}, \mathrm{L}- \\
\text { homocysteine })\end{array}$} & \multirow{2}{*}{$\begin{array}{c}\mathrm{IC}_{50}(\mu \mathrm{M}){ }^{b}(2 \mathrm{mM} \\
\text { betaine, } 1 \mathrm{mM} \\
\text { D,L- } \\
\text { homocysteine })\end{array}$} \\
\hline & & $20 \mu \mathrm{M}$ & $1 \mu \mathrm{M}$ & \\
\hline 19 & & 100 & 96.8 & 0.096 \\
\hline 20 & & 89.8 & 55.3 & nd \\
\hline 21 & & 30 & 0 & nd \\
\hline 22 & & 97.8 & 74 & 5.7 \\
\hline 23 & & 25.5 & nd & nd \\
\hline 24 & & 8.8 & nd & nd \\
\hline 25 & & 0 & nd & nd \\
\hline 26 & & 18.8 & nd & nd \\
\hline 27 & & 9.5 & nd & nd \\
\hline 28 & & 0 & nd & nd \\
\hline
\end{tabular}

\footnotetext{
${ }^{a}$ All assays were done in triplicates and the data obtained were reproducible within $\pm 15 \%$.

${ }^{b}$ All data points for IC 50 values were derived from assays performed in duplicates, and the values obtained from 3 different assays were reproducible within $\pm 10 \%$. nd means not-determined.
} 


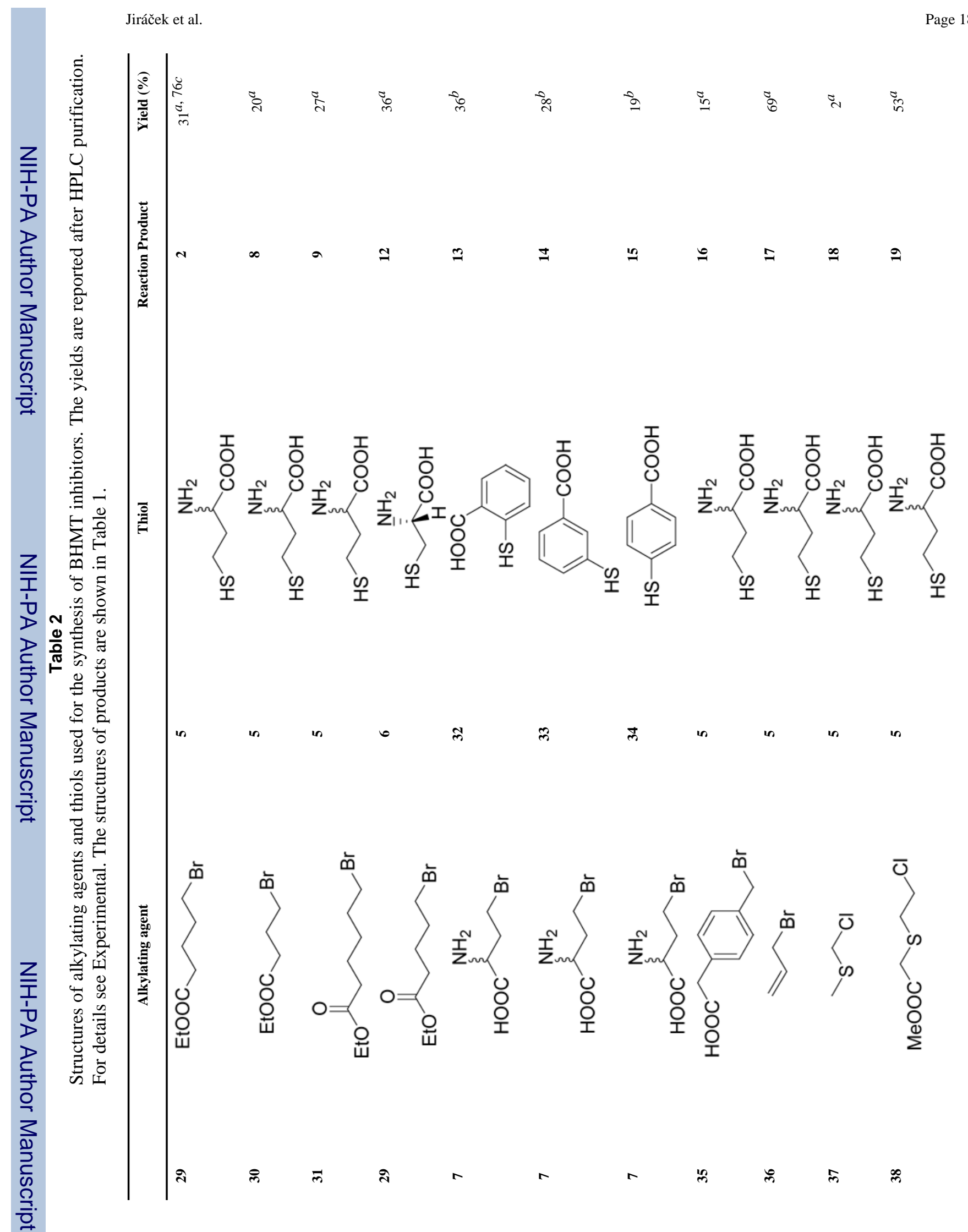

J Med Chem. Author manuscript; available in PMC 2009 January 13. 


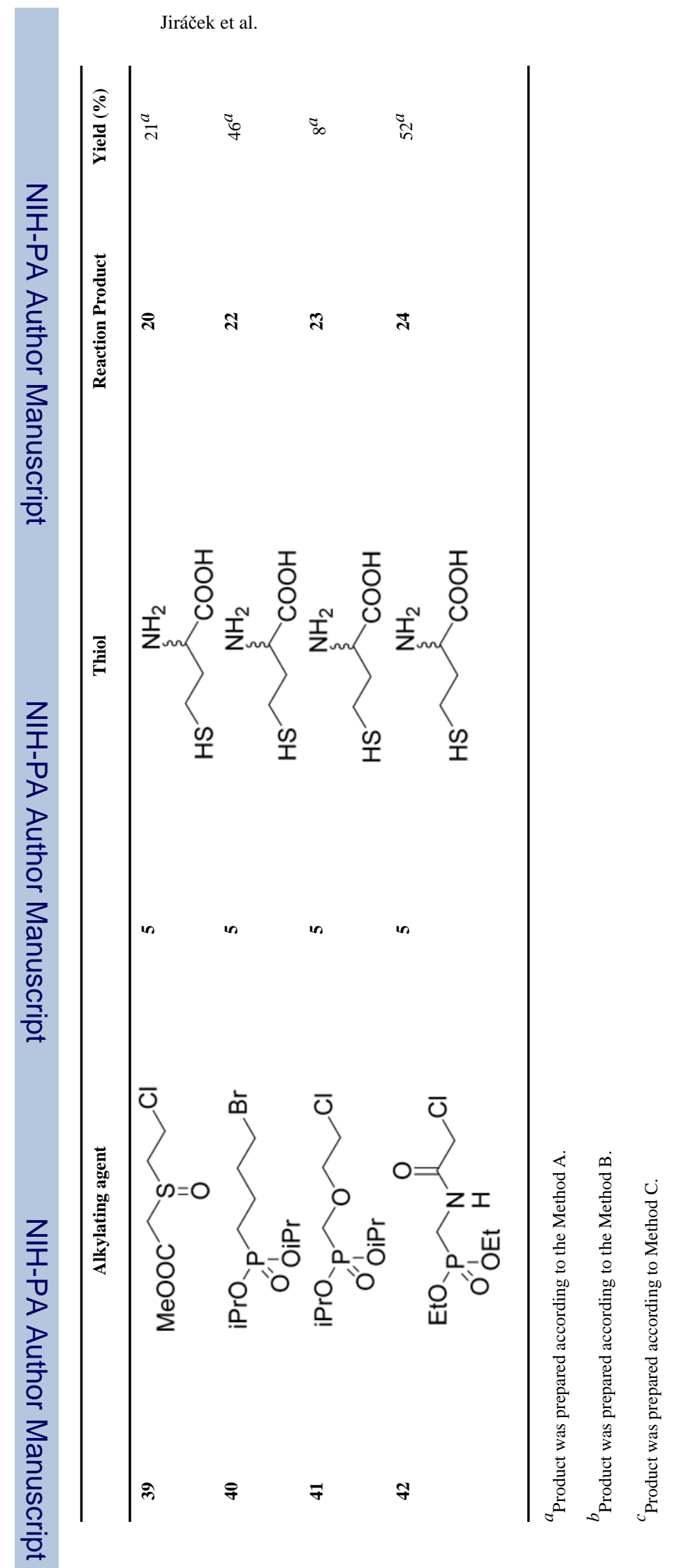

J Med Chem. Author manuscript; available in PMC 2009 January 13. 